\title{
Interplay of changing irrigation technologies and water reuse: example from the upper Snake River basin, Idaho, USA
}

\author{
Shan Zuidema ${ }^{1}$, Danielle Grogan ${ }^{1}$, Alexander Prusevich ${ }^{1}$, Richard Lammers ${ }^{1}$, Sarah Gilmore ${ }^{2}$, and Paula Williams ${ }^{2}$ \\ ${ }^{1}$ Earth Systems Research Center, University of New Hampshire, Durham, NH, 03824, USA \\ ${ }^{2}$ Center for Resilient Communities, University of Idaho, Moscow, ID, 83844, USA
}

Correspondence: Shan Zuidema (shan.zuidema@unh.edu)

Received: 25 March 2020 - Discussion started: 16 April 2020

Revised: 26 August 2020 - Accepted: 14 September 2020 - Published: 10 November 2020

\begin{abstract}
Careful allotment of water resources for irrigation is critical for ensuring the resiliency of agriculture in semiarid regions, and modernizing irrigation technology to minimize inefficient water losses is an important tool for farmers and agricultural economies. While modernizing irrigation technology can achieve reductions in the nonbeneficial use of water, such as bare soil evaporation and nonconsumptive losses, water returned to the landscape is also reduced, often eliminating flow paths that other users rely on. In basins using a combination of surface and groundwater, replenishing aquifer storage by the managed aquifer recharge (MAR) of seasonally available water can mitigate the aquifer drawdown that results from reduced recharge when irrigation efficiency is improved. We examine the effects of MAR on the system-scale efficiency of modernizing irrigation technology and the resulting changes in the reuse of nonconsumptive losses, using a macroscale hydrologic model applied to the semiarid upper Snake River basin (USRB) of western Wyoming and southern Idaho, USA. Irrigation technologies were represented explicitly in the model, and available data informed baseline parameterizations of the irrigation technology. A suite of parameterizations were simulated that updated the existing technologies to be more efficient, both with and without sufficient MAR to cause a stabilization of the aquifer at the present-day head. As expected, simulated changes in irrigation technology resulted in greater downstream export of pristine water and a higher rate of aquifer drawdown when MAR was not simulated. Under current water use and cropping patterns, we were not able to simulate aquifer stabilization and maintain discharge downstream at any level of irrigation efficiency. We found support for the hypothesis that, as efficiency improves, less MAR is
\end{abstract}

required to maintain a stable aquifer than when return flows are reduced due to increased efficiency. To evaluate the hypothesis, we defined the management benefit as a metric that compared the difference between the change in irrigation's net recharge and the change in MAR required as irrigation technology became more efficient. The metric generally indicated that less MAR was needed than net recharge was lost, but only for the most efficient case did the management benefit exceed the MAR needed at the baseline to stabilize the aquifer. Increasing efficiency of irrigation technology reduced the reuse of the gross irrigation derived from prior nonconsumptive losses, but simulating MAR increased reuse for a given parameterization, leading to higher effective irrigation efficiency. We find that local groundwater storage that users depend on is generally more sensitive to management decisions than downstream flows, and the drawdown of the aquifer without MAR always exceeded any decrease in discharge induced by MAR. Improving resource sufficiency in semiarid systems like the USRB will require an array of solutions that will need to balance benefits to local and downstream users.

\section{Introduction}

Access to irrigation water is critical for determining the future resiliency of many agricultural systems (Foley et al., 2011), and the challenges of providing irrigation water require a closer scrutiny of its efficient use (Grafton et al., 2018). The goal of resilient agricultural systems should reflect a global need to reduce water scarcity (Rosa, 2017) with adaptations that are often context specific (Vanham et al., 
2018). Successful management of water resources to protect against water scarcity requires consideration of the specific interactions of multiple factors (Keller and Keller, 1995).

One suite of solutions, where water is scarce, is to modernize the irrigation technology to ensure that the greatest proportion of supplied water is used for beneficial crop growth (Gleick et al., 2011; Jägermeyr et al., 2015, 2016). Improving the classical irrigation efficiency (CIE), the ratio of beneficial consumptive use to gross irrigation abstractions, is critical for meeting agricultural production needs (Jägermeyr et al., 2016) and, additionally, has myriad cobenefits such as reduced energy use or improved water quality (Gleick et al., 2011; Vanham et al., 2018). However, more efficient irrigation systems tend to counterintuitively increase the total water consumed or at least do not decrease water use to the degree expected. As efficiency increases, usually at a cost to the irrigator, the water available from reduced losses can be applied for higher value and more water intensive crops (rebound) or for expanding crop areas (slippage; Contor and Taylor, 2013; Grafton et al., 2018; Pfeiffer and Lin, 2014; Tran et al., 2019), especially when users are encouraged to extract a full water allotment by legal doctrines such as the prior appropriations system used in the US west. Increasing CIE also tends to reduce nonconsumptive losses that downstream users rely on (Foster and van Steenbergen, 2011; Frederiksen and Allen, 2011; Grafton et al., 2018; Grogan et al., 2017; Simons et al., 2015). Nonconsumed losses, the fraction of water applied by irrigation that flows back to the landscape, follow different pathways. The term irrigation returns can refer to flow or flow structures conveying nonconsumed water off irrigated fields and back to a canal system (e.g., Lin and Garcia, 2012), percolation back to a source aquifer (e.g., Dewandel et al., 2008), or more generally to all water not consumed by irrigation water application or delivery (Grogan et al., 2017; Keller and Keller, 1995; Simons et al., 2015); we adopt the latter meaning when referring to irrigation or incidental returns.

Investigators of water resources argue that the reuse of incidental returns increases the basin or global efficiency of supplied water, making technological investments that increase CIE less effective when considered at basin scales rather than at farm scales (Keller et al., 1996). The effect has been observed empirically in well-studied basins (Simons et al., 2015). Increasing CIE is almost certainly a critical component for maintaining the resiliency of agricultural systems when only surface or groundwater supplies irrigation and will necessarily reduce the incidental return to the system. In settings that conjunctively use both surface and groundwater resources, managed aquifer recharge (MAR) can increase the adaptability and resiliency of irrigated agriculture (Dillon et al., 2020). MAR adds water to aquifer storage when available, eliminates the need for infrastructure associated with surface reservoirs, minimizes surface evaporation, and can be less expensive than surface storage (Arshad et al., 2014; Dillon, 2005; Dillon et al., 2019; Maliva, 2014; Scanlon et al., 2016). MAR as part of a conjunctively managed water resource system has been demonstrated to maintain water supplies for irrigated agriculture during drought (Foster and van Steenbergen, 2011; Guyennon et al., 2017; Niswonger et al., 2017; Scanlon et al., 2016; Tran et al., 2020). However, water used for MAR tends to reduce the flow leaving a catchment (Yaraghi et al., 2019), which may have important downstream consequences. In other cases, MAR may affect annual flows slightly (e.g., Niswonger et al., 2017), but can shift the timing of the baseflow entering rivers from the aquifer to the summer months, providing important temperature refugia for aquatic species (Van Kirk et al., 2020).

Despite the potential benefits from coupling MAR with conjunctively managed water sources, there remain challenges in the uptake of the practice (Dillon et al., 2020) to address globally declining aquifer storage (Bierkens and Wada, 2019). Outside specific regulatory intervention, the practice of MAR can marginally reduce the cost of pumping groundwater such that MAR would be expected to result in rebound and slippage effects (Tran et al., 2019) where more land is planted or more water-intensive crops are grown to utilize the available water. Benefits from the conjunctive management of water resources and MAR are projected to be greater in arid environments (Scanlon et al., 2016).

The two interventions presented above, namely increasing the efficiency of irrigation through technological modernization and MAR, appear to synergistically alleviate the drawbacks of each practice. In the absence of slippage, increasing CIE can reduce the incidental recharge (Simons et al., 2015) but retain greater flow within the river, whereas MAR increases recharge but reduces annual river flow (Yaraghi et al., 2019). Balancing the two interventions could potentially achieve a greater resiliency of the irrigated agriculture than either alone. To date, there have been limited analyses to include both strategies in the same framework. Tran et al. (2019) account for specific efficient irrigation practices within the context of multiple potential drivers in a hydroeconomic analysis. Other examples of mechanistic models applied to the problem of MAR and conjunctive resource management have assumed static efficiencies of irrigation technology and crops (Niswonger et al., 2017; Scherberg et al., 2014). Here, we consider the coupled influences of irrigation technology modernization and MAR on water resources to assess the limits to which either intervention could achieve aquifer stabilization while maintaining downstream flows above critical thresholds.

We quantify the impact of changing irrigation efficiency on basin water stocks, aquifer recharge, downstream discharge, and within-basin water reuse using the test case of the upper Snake River basin (USRB) of Idaho, USA, which is an intensive agricultural setting in the semiarid American west (Fig. 1) that relies on both surface and groundwater. Arid and semiarid agriculture can be very important economically; $31 \%-36 \%$ of the nation's net farm income is produced in arid or semiarid regions (Trabucco and Zomer, 2019; USDA 


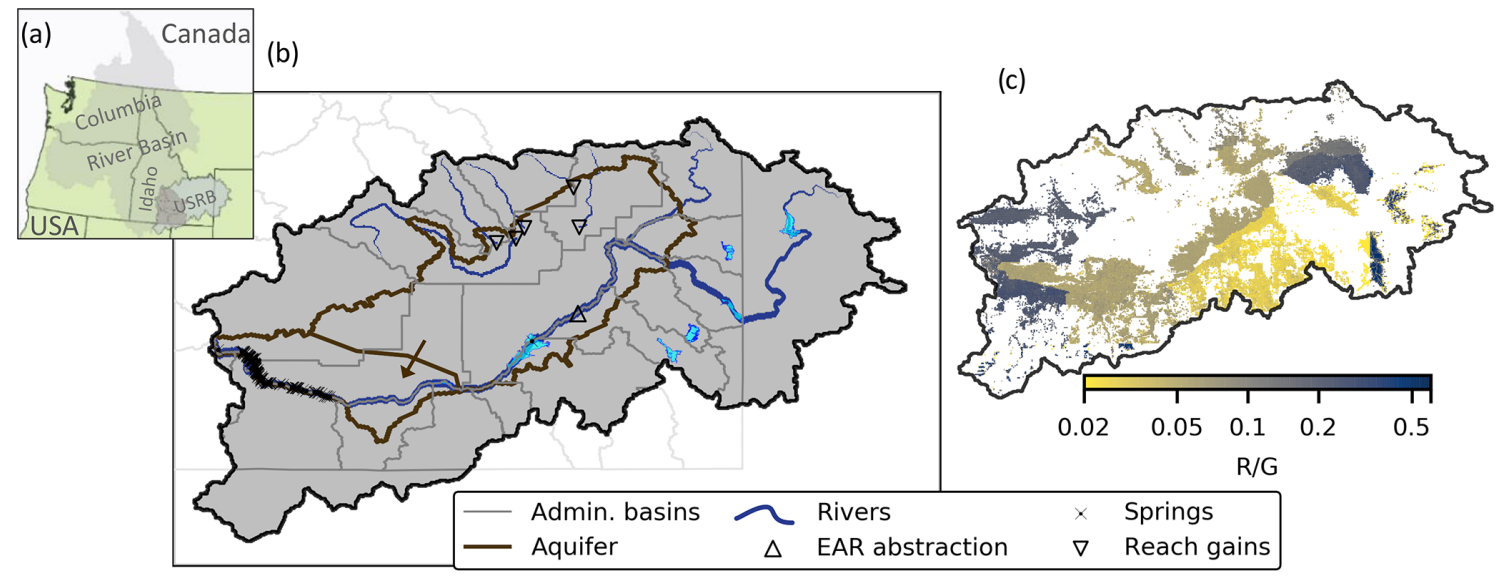

Figure 1. Location of the upper Snake River basin (USRB), a headwater of the Columbia River, in the states of Idaho and Wyoming, USA (a). Configuration of the major hydrologic features of the USRB, including the two compartments conceptualized for the eastern Snake Plain aquifer (ESPA), the locations of the reach gains where the losing rivers drain to the ESPA, the location of the simulated abstractions for enhanced aquifer recharge (EAR), springs where flow from the ESPA drains back to the upper Snake River, the river network scaled by mean annual flow, and the extent of the administrative basins (IDWR, 2015), indicating areas using common surface water sources for irrigation (b). Average fraction of gross irrigation comprised of incidental returns (irrigation reuse $-R$ ) $(\mathbf{c})$.

NASS, 2014). Historic flood irrigation of river water elevated the aquifer head above preirrigation levels, and in the latter half of the 20th century, aquifer storage has declined (Kjelstrom, 1995) due to increasing groundwater pumping and decreasing recharge of surface water as irrigation technology has modernized. Therefore, aquifer stabilization is critical for establishing the resilience of the agricultural system (IWRB, 2016). The implementation of recharge (as MAR) and other management actions to ensure a resilient agricultural system in the USRB may provide important insights relevant throughout arid and semiarid regions where surface evaporative fluxes are similarly high (Carr et al., 2010; Ghassemi et al., 1995; Tal, 2016).

Careful application of improved irrigation efficiency and MAR has been part of ongoing management strategies in the USRB. Water is governed in Idaho under the doctrine of prior appropriation, which allocates water to users according to the date when they first put water to continuous beneficial use. As aquifer drawdown has continued, aquifer recharge, water transfers, and other water conservation efforts have been classified as beneficial uses (Fereday et al., 2018, p. 29). Water users have self-organized in an effort to stabilize the aquifer and optimize use of the water within the USRB and have moved to a more conjunctive management of surface and groundwater resources (Gilmore, 2019). A moratorium on ground water permits in 1992 (Fereday et al., 2018, p. 212) and conservation efforts have resulted in a reduction in consumptive ground water use and motivated the adoption of targets for $0.3 \mathrm{~km}^{3} \mathrm{yr}^{-1}$ of MAR as an intervention (IWRB, 2016); however, aquifer storage may still be declining. Simultaneously, maintaining sufficient downstream flow from the basin is strictly required for senior water rights holders and hydropower generation (IWRB, 1985). The USRB is an ideal setting to assess the trade-offs between within-basin aquifer storage and downstream supply through conjunctive management.

In this study, we frame a series of model parameterizations together to test the hypotheses guided by the key constraints of water resource management in the USRB. We utilized a distributed model of hydrologic function and human water use to estimate the recharge required to (a) stabilize the aquifer under present-day irrigation efficiencies and (b) offset reduced irrigation returns from continued modernization of irrigation technology. We performed simulations introducing progressively more efficient irrigation technology to a baseline representation of the USRB, which required reduced withdrawals from the Snake River but which hastened aquifer drawdown by decreasing recharge of incidental returns. These simulations were paired with counterparts introducing enough managed aquifer recharge to ensure a negligible change in aquifer storage (stabilization) over the same period. We hypothesized that only a fraction of the reduced incidental returns from modernizing technology would be needed to maintain aquifer volume if introduced as MAR. An alternative hypothesis is that asynchronicity in recharge water availability and irrigation demand, coupled with fast flow through the aquifer system, would require greater recharge rates than if the water was introduced as inefficient irrigation and reused contemporaneously. For each simulation, we calculated the total amount of previous incidental returns reused as gross irrigation, using the model's core capability of tracking water sources through all pools of the hydrologic cycle. We hypothesized that simulations with additional MAR would exhibit lower reuse than simulations without MAR because a greater proportion of recent snowmelt would recharge the regional aquifer. Alternatively, additional MAR 
reduces surface water availability and may promote groundwater abstractions that would favor greater reuse, as most irrigation returns percolate to recharge the aquifer.

\section{Methods and data}

The following sections describe the setting (Sect. 2.1), the formulation of hydrologic fractions used here (Sect. 2.2), the experiments conducted (Sect. 2.3), the water balance model (WBM), which is a distributed hydrologic model representing anthropogenic water uses (Sect. 2.4), the model input data (Sect. 2.5), and the validation criteria (Sect. 2.6).

\subsection{Upper Snake River basin}

The upper Snake River basin (USRB) is a semiarid steppe ecosystem with a snowmelt-dominated Mediterranean climate in western Wyoming and southern Idaho, USA (Fig. 1). The $92700 \mathrm{~km}^{2}$ basin is bounded to the east by the Teton Mountains, and to the north by the Sawtooth and Bitterroot mountain ranges. Precipitation over the Snake River plain is generally less than $250 \mathrm{~mm} \mathrm{yr}^{-1}$ but averages at about $400 \mathrm{~mm} \mathrm{yr}^{-1}$ (or $46.3 \mathrm{~km}^{3} \mathrm{yr}^{-1}$ ) over the whole basin, with most water entering the river network as montane snowmelt. The basin is underlain by the Quaternary basalts of the Snake River group (Whitehead, 1992) which form the highly transmissive eastern Snake Plain aquifer (ESPA). Irrigation in the USRB began in the late 1800s, and gravity-drained flood irrigation was the primary mode of irrigation until the mid1900s (Lovin, 2002; Wulfhorst and Glenn, 2002). Incidental recharge from the nonconsumptive losses in irrigation water increased storage in the ESPA and increased discharge from a dense collection of springs in the Snake River canyon between Milner and King Hill, Idaho (Kjelstrom, 1995). Through the latter half of the 20th century, the aquifer head declined due to increasing reliance on groundwater for irrigation and reduced incidental recharge (Moreland, 1976) as the flood-irrigated land transitioned to sprinklers. Aquifer stabilization at today's head is a primary concern in the basin, even though head is above preirrigation levels. State agencies are practicing managed aquifer recharge (MAR), the deliberate infiltration of seasonally available water for use throughout the year, as one technique in the conjunctive management of water resources (IWRB, 2009, 2016).

Groundwater age dating and geochemical analysis established that the downgradient portions of the aquifer consist of between $60 \%$ and $80 \%$ of water used for irrigation and derived from the Snake River (Lindholm, 1996; Plummer et al., 2000). A highly managed network of reservoirs and canals convey about $12 \mathrm{~km}^{3} \mathrm{yr}^{-1}$ of water to croplands (Maupin et al., 2014), equivalent to about $25 \%$ of annual precipitation to the basin. At least $5.5 \mathrm{~km}^{3}$ of water is stored in the three largest reservoirs alone. An additional $2.5 \mathrm{~km}^{3} \mathrm{yr}^{-1}$ is abstracted from the ESPA by irrigators (Dieter et al., 2018;
Maupin et al., 2014), and approximately $5 \mathrm{~km}^{3} \mathrm{yr}^{-1}$ of water returns from the ESPA to the Snake River through a series of springs (Covington and Weaver, 1991; Kjelstrom, 1995). Inflows to the ESPA include several losing rivers at the northern extent of the USRB and the Snake River, which loses water directly to the ESPA near American Falls reservoir (Lindholm, 1996; McVay, 2015). Spring flows out of the ESPA are critical for maintaining an aquaculture industry along the Snake River canyon and constitute a majority of Snake River discharge out of the USRB that supports critical aquatic habitats, hydroelectric generation potential, and the irrigation of downstream agriculture. Water available from the upper Snake River and the ESPA irrigates numerous agricultural products, with dairy forage, beet sugar, and potato being the most economically important (USDA NASS, 2014).

\subsection{Hydrologic fractions and irrigation resource use}

Defining the efficiency of agricultural water use is complicated because water lost nonproductively by one water user may be used productively elsewhere, downstream in the basin, making terms describing efficiency or resource sufficiency specific to the spatial scale considered. We describe irrigation efficiency using hydrologic fractions that describe the fate of the water abstracted from either surface or groundwater sources for the purpose of irrigation (Frederiksen and Allen, 2011; Haie and Keller, 2008; Lankford, 2012; Perry, 2011). Water abstracted as gross irrigation $(G)$ can have three fates when added to irrigated pixels at the plot scale, namely (i) beneficial use $(B)$, which is the irrigation water used for beneficial crop growth, (ii) nonbeneficial consumption $(N)$, which is water evaporated nonbeneficially from soil or canals, or (iii) nonconsumptive loss ( $L$, herein incidental returns or incidental recharge), which is runoff or percolation as a liquid that remains in the basin (Fig. 2). Of these plot-scale fates of gross irrigation water, $B$ and $N$ are both assumed to be terminal because liquid water leaves the domain as vapor or in crops. Incidental returns $(L)$, on the other hand, remain in the system, and fates in the basin scale include export $(X)$ via streamflow at the basin outlet, evaporation $(E)$ from the surface water network, human use $(U)$, reuse as gross irrigation $(R)$, and net storage $(S)$, primarily in the aquifer; however, net storage in surface reservoirs and soil is also calculated.

WBM tracks key component volumes, including incidental returns $(L)$, to all terrestrial compartments of the hydrologic system, permitting direct computation of gross irrigation water reuse $(R)$. In our analysis, we assume that all incidental returns are recoverable and, therefore, do not make a distinction between recoverable and nonrecoverable returns (as in Lankford, 2012) and directly assess the volumes of water recovered in gross abstractions. Gross irrigation reuse $(R)$ is the weighted sum of abstractions consisting of incidental return in each source and is calculated daily based on Eq. (1). 


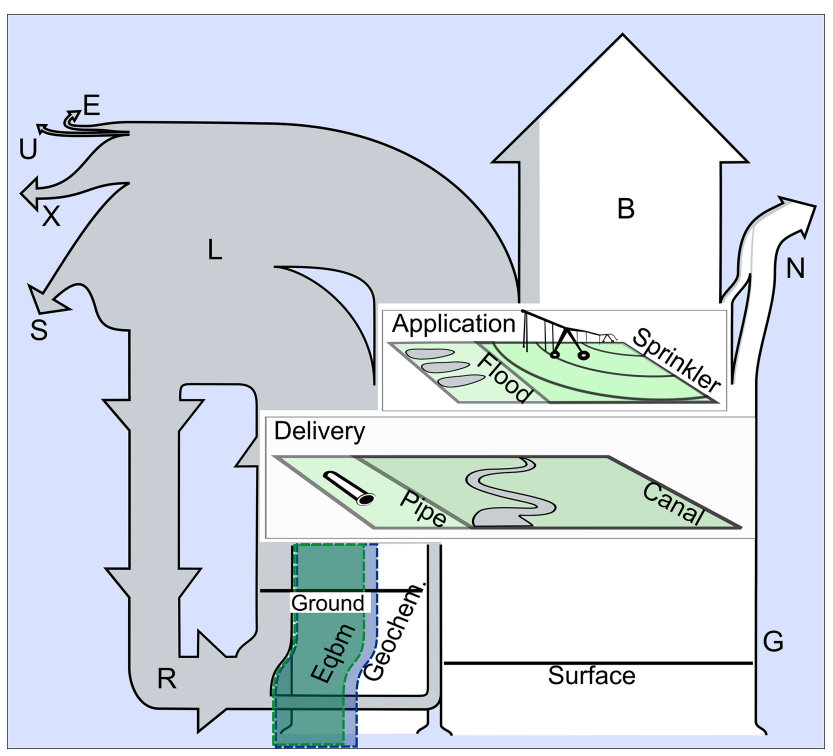

Figure 2. Diagram of fates of water abstracted for irrigation across the USRB. Flow-line widths are scaled proportionally to fluxes across the simulation domain between 2008 and 2017 at the baseline parameterization. White depicts abstractions from pristine sources, whereas water lost nonconsumptively from irrigation delivery or application during the model epoch is gray. Equilibrium (Eqbm) and geochemical (Geochem.) fractions of groundwater abstractions relax assumptions about aquifer water composition and are discussed in Sect. 4.2. Labels of irrigation fluxes are as follows: $G$ - gross irrigation abstractions, $B$ - beneficial consumption by crops, $N-$ nonbeneficial consumption, and $L$ - nonconsumptive losses or incidental returns. The remaining fluxes refer to the fate of incidental returns as follows: $R$ - reuse in gross irrigation, $E$ - evaporation, $U$ - human use, $X$ - export, and $S$ - storage in aquifer, soils, and reservoirs.

$R_{i, j}=I_{\mathrm{Aqf}} \cdot f_{\mathrm{Aqf} i, j}^{\mathrm{irr}}+I_{\mathrm{Rsvr}} \cdot f_{\mathrm{Rsvr} k, l}^{\mathrm{irr}}$,

where $i$ and $j$ are row and column indices for the point of irrigation water application, $I_{\mathrm{Aqf}}$ and $I_{\mathrm{Rsvr}}$ are the abstracted irrigation water from aquifer and surface reservoirs, respectively, $f_{\mathrm{Aqf}}^{\mathrm{irr}}$ and $f_{\mathrm{Rsvr}}^{\mathrm{irr}}$ are the fraction of irrigation return of flow water in aquifer and reservoir water, respectively, and $k$ and $l$ are row and column indices for the pixel of the surface supply reservoir. The metric was summed spatially and temporally and compared to total gross irrigation $(G)$ to calculate a ratio of irrigation water reused within the USRB. Irrigation efficiency is calculated as classical irrigation efficiency (CIE), given by Eq. (2), and effective irrigation efficiency (EIE) following the quantity (Type N) model of Haie and Keller (2008), given by Eq. (3).

$$
\begin{aligned}
& \mathrm{CIE}=\frac{B}{G} \\
& \mathrm{EIE}=\frac{B}{G-R} .
\end{aligned}
$$

Note that $R$ does not quantify how many times a given parcel or all irrigation water is reused, on average, as per the distinct definition of $R$ as the index of unsustainable groundwater reuse in Grogan et al. (2017). Instead, it identifies what portion of total irrigation water has been through cycles of use (Fig. 2).

\subsection{Experiment structure}

There is a strong connection between the upper Snake River and ESPA in the USRB, both through reach gains and sinks from the Snake River to the ESPA and from springs back to the Snake River. These connections are not unlike alluvial aquifers for which conjunctive management of water resources is most common (Foster and van Steenbergen, 2011). We therefore use predictive inference (Ferraro et al., 2019) to assess the potential for trade-offs between downstream flow and aquifer drawdown as irrigation efficiency and MAR change independently. We should note that the experiments we perform potentially violate water law and precedent in the basin (Gilmore, 2019), so natural experiments (Penny et al., 2020) to interrogate similar processes are impractical. To test our hypothesis that only a fraction of reduced incidental recharge is needed as managed aquifer recharge (MAR) to increase water availability basinwide, we simulate a suite of alternative model parameterizations to capture the increasing irrigation efficiency (as CIE) paired with and without MAR. In the WBM, we introduce a fraction of daily flow from the Snake River, immediately above the American Falls Reservoir directly to the ESPA, to represent recharge as an intervention. Because our simulations also reflect changes in aquifer recharge related to changing flow in the river source, we use the term enhanced aquifer recharge (EAR) to refer to all induced changes in aquifer recharge in our model simulations. Specific changes to simulated irrigation technologies for each parameterization are described below. We then assess our hypothesis by calculating a management benefit (MB) metric that compares the change in net incidental recharge to the change in EAR required for aquifer stabilization by the difference for each parameterization. The MB is the magnitude by which the increase in required EAR is less than the loss in net incidental recharge and is calculated by Eq. (4).

$\mathrm{MB}=\left(I_{\mathrm{rch}}^{*}-I_{\mathrm{rch}}\right)-\left(\mathrm{EAR}-\mathrm{EAR}^{*}\right)-\frac{\mathrm{d} V_{\mathrm{ESPA}}}{\mathrm{d} t}$,

where $I_{\text {rch }}$ is the net incidental recharge (incidental recharge minus groundwater abstraction), EAR is the enhanced aquifer recharge flux, and ${ }^{*}$ represents the flux at the presentday baseline. For each parameterization, we compare the change in aquifer storage with the relative change in discharge from the baseline to evaluate the combination of aquifer and streamflow capture needed to support irrigation abstraction at a given level of efficiency. In this paper, our 
definition of streamflow capture is general, including any decreasing discharge out of the basin due to altered management practice, and does not specifically mean the change in streamflow and recharge resulting from increased groundwater pumping (Konikow and Leake, 2014).

For each simulated suite of irrigation technology parameters, we run paired simulations with and without EAR. For EAR simulations, we target aquifer stabilization, which is defined as a long-term (e.g., decadal) average change in groundwater storage of the entire ESPA close to zero during the contemporary time period from 2008 through 2017 (see Eq. 5).

$$
\frac{\mathrm{d} V_{\mathrm{ESPA}}}{\mathrm{d} t} \sim 0:-0.1<\frac{\mathrm{d} V_{\mathrm{ESPA}}}{\mathrm{d} t}<0.1\left[\mathrm{~km}^{3} \mathrm{yr}^{-1}\right] .
$$

Once the values for ESPA exchange were calculated for the baseline representation, simulations were conducted with these values for each of the nine more efficient irrigation technology parameterizations (Table 1). Then, additional EAR was estimated through manual calibration to achieve a stabilization of the ESPA volume for the baseline and each of the efficiency parameterizations. For all model simulations, aquifer stabilization, basin discharge, and hydrologic fractions, including reuse, were calculated from the hydrologic model output. In calculating MB, the change in aquifer volume is subtracted to account for small deviations from aquifer stability that remain after calibration.

\subsection{Water balance model}

We used the University of New Hampshire water balance model (WBM) to characterize the water balance and assess water resource fates (Vörösmarty et al., 1989; Wisser et al., 2010). WBM is a distributed hydrologic model utilizing conceptual soil, surface runoff, and shallow groundwater pools and a 1D river network utilizing hydrologic routing schemes and representations of human controls on the hydrologic cycle, such as dams, impervious surfaces, irrigation, livestock, industrial, and domestic water use. WBM tracks specific components of water fluxes, notably irrigation returns, through each represented pool, assuming each pool is well mixed at each daily time step (Grogan et al., 2017).

Several modifications were implemented in WBM for the present work; a more complete description of the fundamental WBM model structure is available elsewhere (Grogan, 2016; Grogan et al., 2017; Wisser et al., 2010). In previous applications of water tracking in WBM (Grogan et al., 2017), component stocks were adequately cycled to be representative of the various components following model spin up. To address concerns that water components retain a memory of assumptions at the initialization, owing to a new groundwater representation described below, all stored water at the model initialization was tracked as relict water, which is a measure of water remaining in the system prior to the dynamic model simulation epoch. We introduced an upper volumetric bound to the surface runoff pool to rectify a low bias in runoff during extreme precipitation and snowmelt events. The fraction of surplus soil water (soil water content above field capacity) that flows to the shallow groundwater pool ( $\gamma$; unitless) and its complement $(1-\gamma)$, which is directed to the surface runoff pool, are generally about 0.5 and robust in a range from 0.4 to 0.6 (Grogan et al., 2017; Samal et al., 2017; Stewart et al., 2013; Zuidema et al., 2018). Due to the highly permeable geology found along the eastern Snake Plain, $\gamma$ was increased to represent high initial infiltration rates common throughout the eastern Snake Plain (IDWR, 2013). For our simulations, $\gamma$ was spatially variable (ranging from 0.38 to 0.96 ; mean $=0.73$ ) based on elevation as a proxy for the extents of the eastern Snake Plain (Fig. S1 in the Supplement). Other parameters defining the major hydrologic controls were established by work across multiple scales (Grogan et al., 2017; Samal et al., 2017; Stewart et al., 2013; Wisser et al., 2010; Zuidema et al., 2018) and were not calibrated for this application in the USRB.

Several features were added to WBM to implement the experiment. To represent the intense management of USRB water resources, reservoir outflow from the three largest reservoirs was specified; therefore, WBM predicted reservoir volume as a consequence of managed release. Irrigation technology was revised in WBM to a process-based representation that redistributes inefficient irrigation water via surface runoff flows, groundwater percolation, and evaporation during both the delivery and application stages. The system explicitly represented nonbeneficial consumption as the evaporation of sprinkler mists and evaporation from canal and soil surfaces, using technology-specific parameters reflecting countywide averages from USGS water use statistics (Dieter et al., 2018; Maupin et al., 2014). A representative fraction of $4 \%$ of sprinkler-applied water is evaporated as mist (Bavi et al., 2009; McLean et al., 2000; Uddin et al., 2010). Furthermore, during the irrigation season, water is assumed to be evaporating at potential rates throughout the canal network. We assume crop evapotranspiration (ET) is required (i.e., beneficial) for both transpiration and salt flushing, but water applied during an irrigation event that is in excess of the daily crop demand wets the soil above the field capacity. Incidental losses during application followed Jägermeyr et al. (2015), and we used their estimates of the distribution uniformity parameter that prescribed the excess water needed to satisfy net irrigation demand, based on the type of technology in the form of water from either drip, sprinkler, or flood. Excess water evaporates (nonbeneficially) at the potential rate, and remaining liquid water is returned nonconsumptively at the end of the time step via either percolation or runoff if the vertical hydraulic conductivity is too low. The algorithm describing irrigation water fates is detailed in the Supplement.

We defined surface water sources for each administrative basin in Idaho (IDWR, 2015) to come from one or more reservoirs based on the canal network's distribution (Fig. S2). All daily surface abstractions for irrigation are made from the 
Table 1. Definition of efficiency parameterizations.

\begin{tabular}{lrrrr}
\hline & \multicolumn{4}{c}{ Fraction of } \\
\cline { 2 - 5 } Parameterization & $\begin{array}{r}\text { Baseline surface } \\
\text { irrigation }\end{array}$ & $\begin{array}{r}\text { Open-surface } \\
\text { conveyances }\end{array}$ & $\begin{array}{r}\text { Unlined } \\
\text { canals }\end{array}$ & $\begin{array}{r}\text { Direct } \\
\text { irrigation }\end{array}$ \\
\hline Baseline & 1.0 & 0.83 & 1.0 & 0.00 \\
Eff.A & 0.89 & 0.82 & 0.95 & 0.10 \\
Eff.B & 0.86 & 0.80 & 0.8 & 0.10 \\
Eff.C & 0.82 & 0.70 & 0.60 & 0.10 \\
Eff.D & 0.77 & 0.60 & 0.40 & 0.10 \\
Eff.E & 0.73 & 0.50 & 0.20 & 0.10 \\
Eff.F & 0.53 & 0.40 & 0.15 & 0.33 \\
Eff.G & 0.40 & 0.30 & 0.10 & 0.50 \\
Eff.H & 0.27 & 0.15 & 0.05 & 0.67 \\
Eff.I & 0.0 & 0.0 & 0.0 & 1.00 \\
\hline
\end{tabular}

pool of source reservoirs providing water to each administrative basin, proportional to their available storage. Groundwater abstractions for the irrigation of croplands were calculated as the difference in demand not satisfied by surface water sources. A more detailed aquifer representation was needed here than in previous WBM studies. We simulated the ESPA over the same extent as the ESPAM2.1 model (IDWR, 2013), using a lumped formulation that received distributed recharge from natural and incidental sources and reach gains from specific losing rivers (Fig. 1), provided a pool of groundwater available for irrigation, and discharged to a series of 213 springs along the Snake River canyon (Covington and Weaver, 1991). Discharge from springs was head dependent, and subdaily head and outflow were calculated numerically using a third-order scheme (Bogacki and Shampine, 1989). We represented the aquifer as the upgradient (northeast) and downgradient (southwest) lumped compartments (Fig. 1) to reflect two characteristic types of water identified by Plummer et al. (2000), namely old groundwater in the upgradient portion and young water derived from incidental recharge of Snake River water in the downgradient or southwestern portion. Storage parameters were estimated for each section, where the upgradient-specific yield is 0.06 and the thickness of the aquifer is $250 \mathrm{~m}$; the downgradient specific yield is 0.05 and the thickness is $220 \mathrm{~m}$ (Garabedian, 1992; IDWR, 2013; Whitehead, 1992). We represented the hydraulic connection between the ESPA and the American Falls Reservoir (Garabedian, 1992; IDWR, 2013) as being a drain or spring pair. Additional details of the implementation of the lumped aquifer solution are presented in the Supplement.

\subsection{Input data}

We used a topological network of the upper Snake River basin (USRB) that covers an area of $92900 \mathrm{~km}^{2}$ at a spatial resolution of $30 \mathrm{arcsec}$ (approximately $780 \mathrm{~m}$ ), based on HydroSHEDS (Lehner et al., 2008), but refined it to bet- ter represent the drainage as mapped by the US Geological Survey's National Hydrography Data (USGS, 2019). Reservoir data were derived from the National Inventory of Dams (USACE, 2016) and updated manually to include additional dams, refine reservoir capacities, remove secondary structures on reservoirs, and refine the locations and upstream drainage areas. Reservoir outflow came from observed flow data from USGS gaging stations located immediately downstream of three primary irrigation reservoirs, including gauge 13011000 in Moran, WY, below the Jackson reservoir, gauge 13032500 in Irwin, ID, below the Palisades reservoir, and gauge 13077000 in Neeley, ID, below the American Falls reservoir. No data regarding direct abstractions from reservoirs were available from these sources. Additionally, we increased the total capacities of these three reservoirs represented in WBM by $10 \%$ to approximate the storage of their downstream canal systems. There were 128 dams and corresponding water bodies in the USRB domain. WBM simulations used gridMET (Abatzoglou, 2013) for the contemporary precipitation and temperature and MERRA2 for the open water evaporation (Gelaro et al., 2017). We utilized a temperature-based evaporation equation (Hamon, 1963) to calculate potential evapotranspiration (PET) and a temperature-index-based snow accumulation and melt formulation (Willmott et al., 1985). Human population density, which controls both domestic and industrial water demand, came from the Socioeconomic Data and Applications Center (SEDAC) Gridded Population of the World (Center For International Earth Science Information Network and Socioeconomic Data and Applications Center, Columbia University, 2016). WBM simulations used Food and Agricultural Organization (FAO) estimates of livestock density for cattle (Steinfeld et al., 2006) at $5 \mathrm{~min}$ resolution, following Wisser et al. (2010). These data compared favorably with USDA National Agricultural Summary Statistics (NASS) for 2005 but exhibit more realistic spatial variability than county-level averages in NASS. Over the USRB domain, NASS livestock 
density is approximately a 2 head $\mathrm{km}^{-2}$ density, representing a low bias of the FAO data of less than $1 \%$. We utilized the USDA Soil SURvey GeOgraphic (SSURGO) data to parameterize the available water capacity for USRB soils. We specified a rate of $115 \mathrm{mmd}^{-1}$ for percolation below land occupied by canals and for irrigated lands exceeding saturation, following findings from the Idaho Water Resources Board (IWRB, 2016).

WBM adapts FAO's methodology (Allen et al., 1998) to estimate crop water requirements based on reference ET, soil moisture, and crop coefficient $\left(k_{\mathrm{c}}\right)$ and is detailed in previous work (Grogan et al., 2017; Wisser et al., 2010). Here, we utilized the US Department of Agriculture's Crop Data Layer (CDL) estimates of crop types and land cover at a $30 \mathrm{~m}$ resolution (Han et al., 2012) after remapping crop groups (Table S1 in the Supplement). The proportions of irrigation delivery technologies were spatially homogenous and reflected the average lengths of technologies in the USGS National Hydrography Dataset (http://nhd.usgs.gov, last access: 9 July 2020). The relative proportions of application technology varied by county, following USGS surveys (Dieter et al., 2018; Maupin et al., 2014). To address our first two hypotheses, parameterizations were defined to represent nine progressively more efficient suites of irrigation technology, identified here as parameterizations Eff.A through Eff.I. The nine parameterizations are controlled by the relative fraction of flood irrigation (with corresponding increases in sprinkler area), the relative fraction of drip irrigation (with corresponding decreases in flood and sprinkler area), the fraction of canals (with corresponding increases in pipes), and the percolation factor of canal bottoms (Table 1).

\subsection{Model validation metrics}

Model assessment used a composite objective function that described model observation misfit across four primary metrics. We compared the (1) monthly flow from the springs draining the ESPA against total gains minus diversions between the Kimberly and King Hill, Idaho, USGS gaging stations provided by the IDWR (Jennifer Sukow, personal communication, 2011); (2) annual gross and surface water abstractions for irrigation over the USRB, aggregated by county for the years 2010 and 2015, and compared to USGS water use statistics (Dieter et al., 2018; Maupin et al., 2014); (3) seasonal river discharge at locations upstream of actively regulated reservoirs at USGS gauges 13010065 (Flagg Ranch, Wyoming), 13137500 (Trail Creek, Ketchum, Idaho), and 13039500 (Henry's Fork, Henry's Lake, Idaho); and (4) seasonal storage within the actively regulated Snake River reservoirs against data from the US Bureau of Reclamation HydroMet database. A standard suite of statistics are used to assess each of these metrics, and we report percent bias and Nash-Sutcliffe efficiency (NSE) for the period between 2008 and 2017. Manual parameter calibration established reasonable estimates for the water exchange be- tween the Snake River and ESPA near American Falls. Exchange between the Snake River and ESPA affects the reservoir volume estimates and aquifer volume (and therefore spring flows) and can affect the surface irrigation estimates, as abstractions are necessarily curtailed if the American Falls reservoir does not have sufficient storage to meet the demand. Therefore, focusing on all four metrics to establish performance was necessary.

\section{Results}

\subsection{Model validation}

Though most processes within the model were uncalibrated, WBM accurately represented observations of the key fluxes in the USRB that we tested. The spatial distribution of abstractions is accurate for both total and surface sources of irrigation water (Fig. S3). Mean annual discharge from springs draining the ESPA is unbiased (Fig. S4). Interannual variability in peak runoff is generally well captured (Fig. S5a), and the timing of peak runoff generation from snowmelt is accurate; however, the onset of snowmelt tends towards an early bias in most years. Though discharge from the headwaters of the upper Snake River in the Teton Mountains was well characterized (e.g., monthly discharge NSE 0.72 and bias of $13 \%$ at Flagg Ranch, WY; Fig. S5a), the intense management of reservoirs in the USRB results in cascading errors in simulating the timing, rates, and magnitudes of reservoir drawdown (Fig. S5). Representing the hydrology of heavily managed basins such as the USRB, whereas most large reservoirs are managed as a single system (not just three reservoirs where we forced outflows to observations), with macroscale models is challenging, and the development of robust representations of the management of reservoir series are important directions for future research (Adam et al., 2007; Masaki et al., 2017).

To address our specific hypotheses, we compared a series of model parameterizations from a common baseline. Biases in the model representation of the USRB, from utilizing a minimally calibrated model, are common between each hypothetical parameterization of changing irrigation efficiency. Therefore, the differences between model simulations are informative of the effect that interventions of irrigation technology have on semiarid agricultural basins in general. Inferences specific to the USRB's response to similar management interventions are inevitable, so it is worth considering how the known model misfit could influence interpretations of the fate of incidental returns, irrigation reuse, and the effectiveness of coupling EAR with increased irrigation efficiency for the USRB specifically. We note several obvious biases between the model simulation at the baseline and observations. First, WBM predicts the onset of snowmelt early in most years (Fig. S5a), which leads to overfilling of the major reservoirs along the cascade of reservoirs through the up- 
per Snake River. Early season discharge leads to overfilling of reservoirs compared to observations and then the shunting of water downstream, causing both a high bias in the early season discharge at the basin outlet (Fig. S5f) and less water in storage late in the season. Excess discharge at the outlet ranges between 0.65 and $8.75 \mathrm{~km}^{3} \mathrm{yr}^{-1}$, with a median of $2.86 \mathrm{~km}^{3} \mathrm{yr}^{-1}$. Furthermore, the early shift in snowmelt makes less water available in the reservoir cascade later in the year, leading to an overdraft of the Palisades reservoir late in the irrigation season in 2010, 2012, 2015, and 2016 and therefore less water is available to the American Falls reservoir in those years. Model simulations that more accurately captured the timing of snowmelt onset with the known reservoir management would retain more snowmelt in the reservoir cascade, making more snowmelt available to maintain reservoir levels near observations and for irrigation. Therefore, less groundwater would likely be used for irrigation, resulting in less aquifer drawdown and a lower rate of gross irrigation reuse of incidental returns.

We also note that seasonal dynamics of the water table and, therefore, discharge through springs were highly damped relative to observations, which results from our lumped aquifer parameterization. Prior analysis shows that annual cycles in spring discharge result from fluxes that occur within $20 \mathrm{~km}$ of the springs (Boggs et al., 2010). Though mean spring discharge is unbiased, incidental recharge to the aquifer and pumping from the aquifer are spread over the two compartments of the aquifer and exceed the space scales that would create seasonal dynamics. Suppressed seasonality of spring discharge could reduce the seasonality of downstream flows; however, there are no major abstractions of surface water downstream of spring in our representation of the USRB. Moreover, seasonal head fluctuations could reduce pumping by either drying wells or increasing pumping costs; however, these dynamics are unrepresented in the model and have not been widely reported as affecting wells drawing from the ESPA. Therefore, we consider that the results of our model would be unchanged if seasonal dynamics in the aquifer head were more closely aligned with observations.

Simulated irrigation abstractions are generally low compared to USGS observations (Fig. S3) and could be increased by either forcing the lower efficiency of the baseline irrigation practice or increasing evapotranspiration from crops. The efficiency of irrigation technologies is reasonably characterized empirically in the baseline parameterization; however, uncertainties with regard to specific technological parameterizations certainly exist. For instance, the distribution uniformity parameter that controls the amount of water applied to a field during an irrigation event can vary dramatically at field scales (Burt et al., 1997). Following the analysis of Jägermeyr et al. (2015), we use the parameters selected from their sensitivity analysis that optimized trade-offs between crop yield and water use for each technology type. The distribution uniformity, and the parameters controlling percolation beneath canals and soil infiltration rates, could create less efficient irrigation technologies that would reduce the bias in irrigation water used; however, we avoided calibrating to avoid overfitting with respect to drivers of incidental returns and nonbeneficial use. Though unbiased at global scales, the potential evapotranspiration calculation used here (Hamon, 1963) may underestimate the flux from the semiarid environment of the USRB. Alternatives, such as the PenmanMonteith equation (Monteith, 1965), resulted in a poorer representation of the spatial variability in irrigation abstractions, though the whole-basin total abstractions were less biased. An increase in irrigation abstractions from higher potential evapotranspiration would increase the baseline CIE by increasing the beneficial consumption of crops, while increasing nonbeneficial use and incidental returns only slightly. The excess volume of water lost via simulated discharge from the early onset of snowmelt is less than the difference between WBM's and USGS's use estimates for gross irrigation water use in the USRB. Increased abstraction may reduce water available for EAR, leading to greater tradeoffs between changing streamflow capture and aquifer drawdown.

\subsection{Comparison of baseline simulations with other studies}

The fraction of incidental returns to the ESPA predicted by simulations is a critical factor for interpreting these results, and we compared simulations with both empirical estimates and previous modeling studies. The fraction of incidental returns in the ESPA storage was lower than the fraction of incidental returns entering the aquifer as recharge because the aquifer equilibrates over longer timescales than those for which the simulations were conducted. The composition of the aquifer was dominated by relict water because we identified all water in the system as relict at the end of the spin up in these simulations to permit tracking the fate of all incidental returns. Following sufficient runtime, the model, as parameterized at the baseline, should equilibrate to a composition of at least $60 \%$ irrigation returns (Table 2). In 1994 and 1995, isotopic and geochemical tracers showed that water in downgradient portions of the ESPA and in spring outflows consisted of approximately $75 \%$ incidental returns from the Snake River (Plummer et al., 2000). The fraction of incidental returns in the ESPA recharge was lower in this analysis than what was estimated from tracers because (a) our estimate represents a dilution of incidental returns over the entire ESPA, not local flow paths sampled near the down-gradient portions of the ESPA where agriculture is concentrated, and (b) CIE efficiency from changing irrigation technology decreased the rates of incidental recharge between 1994 and 2010 (Dieter et al., 2018; Maupin et al., 2014). These differing assumptions of the amount of irrigation return water in the ESPA is accounted for in our analysis.

The IDWR's ESPAM2.1 apparently predicted a greater net recharge from irrigated agriculture to the aquifer; how- 


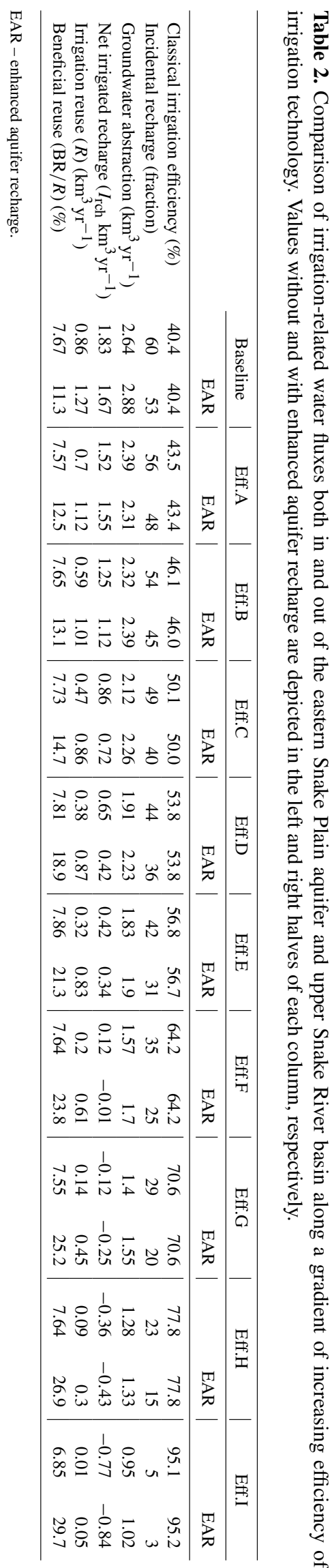

ever, direct comparisons are complicated by differing simulation time periods and definitions of simulated fluxes (IDWR, 2013). The ESPAM2.1 estimates of net recharge accounted for all infiltration from irrigated croplands, whereas we report the infiltration explicitly from applied irrigation water. Net recharge predicted by ESPAM 2.1 was $3.4 \mathrm{~km}^{3} \mathrm{yr}^{-1}$, greater than the $1.9 \mathrm{~km}^{3} \mathrm{yr}^{-1}$ of net incidental recharge predicted by WBM at the baseline parameterization. The ESPAM2.1 simulation period was earlier (1980 through about 2008), but that model did not exhibit trends in net recharge that would make it consistent with WBM during the later simulation period used. While the greater groundwater abstractions in the WBM baseline parameterization $\left(2.7 \mathrm{~km}^{3} \mathrm{yr}^{-1}\right)$, compared to ESPAM2.1 $\left(2.2 \mathrm{~km}^{3} \mathrm{yr}^{-1}\right)$, may partially explain the difference in net incidental recharge, groundwater abstractions were still lower than the $3.4 \mathrm{~km}^{3} \mathrm{yr}^{-1}$ estimated by Frans et al., 2012). Both the crop-type data and meteorological data employed by ESPAM2.1 differ from the data used here (Sect. 2.2). Wisser et al. (2008) found that the combined influence of climate and crop land cover data resulted in uncertainty in the crop irrigation demand of up to $50 \%$, consistent with differences between WBM and ESPAM2.1. Considering the low bias in WBM's simulated gross irrigation compared to USGS wateruse estimates (Fig. S3) and the lower rate of net recharge in WBM, we expect that our rates of incidental returns to the system, and therefore irrigation reuse, are likely underpredicted, at least with respect to the ESPAM2.1. Furthermore, the reduction in net recharge with modernization could be more significant than simulated here, making our estimates of the MB metric potentially low (i.e., conservative).

\subsection{Baseline simulation water budget and fates}

The major fluxes of irrigation abstractions are shown schematically in Fig. 2. Beneficial consumption $(B)$ was about $3.52 \mathrm{~km}^{3} \mathrm{yr}^{-1}$, representing $40 \%$ of the gross irrigation abstractions $(G)$ at baseline irrigation. Nearly all incidental returns percolated due to the highly permeable geology underlying most of the USRB. About $10 \%$ of gross irrigation abstracted, or $0.86 \mathrm{~km}^{3} \mathrm{yr}^{-1}$ of water (ranging from 0.43 to $1.11 \mathrm{~km}^{3} \mathrm{yr}^{-1}$ ), was reused for irrigation each year under the baseline conditions (Figs. 1 and 2). Figure 1 shows the spatial intensity of irrigation water reuse $(R)$ for the baseline parameterization. Major controls on the spatial distribution of irrigation reuse included the (a) administrative basin extent and the balance of incidental returns in reservoirs acting as irrigation source, (b) upstream catchment area, and (c) presence of the ESPA. Reservoirs received incidental returns in runoff from upstream croplands. The fraction of incidental returns in surface irrigation for entire administrative basins reflect the fraction of irrigation returns stored within the collection of source reservoirs. Therefore, the reuse changed abruptly at administrative basin boundaries (Fig. 1). Source reservoirs were not defined in Wyoming at 
the eastern margin of the model domain. Here, water was provisioned by locating the nearest downstream available water, so $R$ increased as incidental returns accumulated along downstream flow paths. Irrigation reuse changed along the margins of the ESPA as the incidental recharge contributed by groundwater abstractions was characterized by the shortturnover shallow groundwater pool outside the ESPA region. Therefore, in the extreme west of the domain, shallow groundwater contained a high fraction of incidental recharge relative to the ESPA.

Beneficial (BR) and nonbeneficial reuse (NR) is calculated explicitly in the model as the beneficial and nonbeneficial fraction of gross irrigation reuse. The fraction of beneficial reuse to gross irrigation reuse $(\mathrm{BR} / R)$ is roughly equal to the basinwide average classical efficiency $(B / G)$, with slight spatial differences accounting for differing technologies in locations where reuse is more prevalent. Approximately $0.35 \mathrm{~km}^{3} \mathrm{yr}^{-1}$ of beneficial irrigation consumption is derived from irrigation reuse under our baseline parameterization (Table 2), representing about $10 \%$ of the total beneficial consumption (as $\mathrm{BR} / B$ ) and $8 \%$ of the total incidental returns $($ as $\mathrm{BR} / L)$.

\subsection{Effects of irrigation modernization}

Modernization of irrigation technology leads to reduced aquifer storage and increased export of water from the basin. Specifically, we find that the modernization decreased plotscale incidental returns from 4.6 to $0.2 \mathrm{~km}^{3} \mathrm{yr}^{-1}$ (Fig. 3a). As a result, the rate of loss from aquifer storage (drawdown) increases from about 0.7 to about $1.7 \mathrm{~km}^{3} \mathrm{yr}^{-1}$ when simulated without EAR (Fig. 3b), while average annual discharge leaving the basin increases from 10.8 to $12.2 \mathrm{~km}^{3} \mathrm{yr}^{-1}$ (Fig. 3d; Table 2). In these experiments, crop use is independent of irrigation process, so no changes in beneficial crop evapotranspiration are simulated (Fig. 3a). Nonbeneficial consumption decreased from $0.62 \mathrm{~km}^{3} \mathrm{yr}^{-1}$ in the baseline to $0.01 \mathrm{~km}^{3} \mathrm{yr}^{-1}$ for parameterization Eff.I. The high rates of percolation exceeded the evaporative demand from bare soils so that incidental recharge was much greater than the nonbeneficial consumption from bare soil evaporation.

\subsection{Enhanced aquifer recharge}

When simulated, EAR ranged from $1.1 \mathrm{~km}^{3} \mathrm{yr}^{-1}$ (baseline) to $2.4 \mathrm{~km}^{3} \mathrm{yr}^{-1}$ (Eff.I) to maintain aquifer volume within $0.11 \mathrm{~km}^{3} \mathrm{yr}^{-1}$ (Fig. 3; Table 2). The $120 \%$ increase in EAR from baseline to the most efficient parameterization offset a loss of $4.3 \mathrm{~km}^{3} \mathrm{yr}^{-1}$ from incidental recharge to the aquifer. Incidental recharge from irrigated crops was $4.5 \mathrm{~km}^{3} \mathrm{yr}^{-1}$ at the baseline, and the net recharge from irrigated agriculture (incidental recharge minus abstractions) was positive at $1.8 \mathrm{~km}^{3} \mathrm{yr}^{-1}$ at the baseline with or without EAR. Incidental returns represented $60 \%$ of the water entering the ESPA under baseline conditions (Table 2). As irrigation efficiency in- (a)

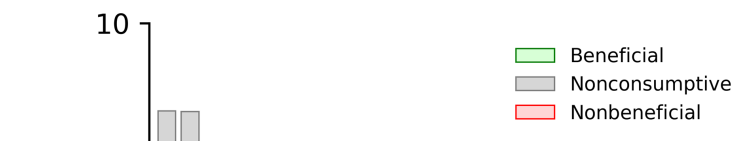

(b)

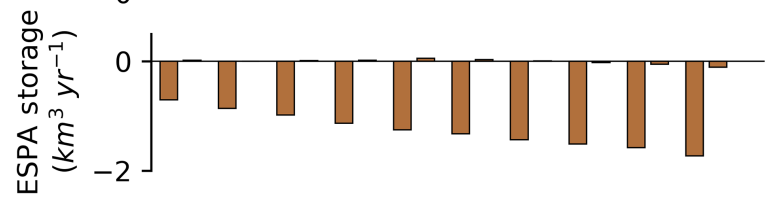

(c)

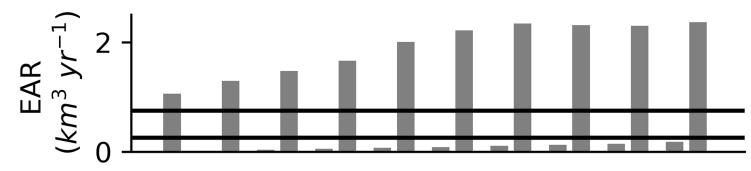

(d)

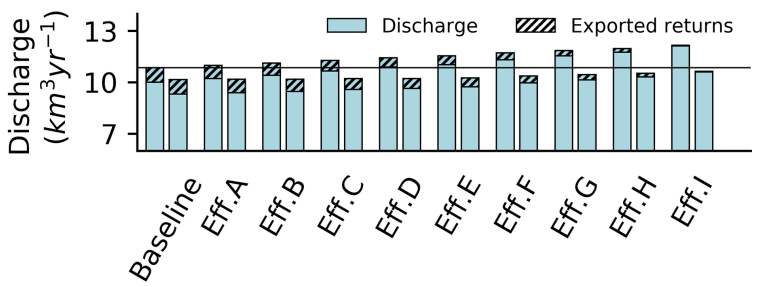

Figure 3. (a) Critical water fluxes across efficiency scenarios paired by simulations without (left) and with (right) enhanced aquifer recharge (EAR). Component fractions of gross irrigation water for the USRB as 2008-2017 averages. (b) Average change in volume of the ESPA. (c) Enhanced aquifer recharge (recharge to the ESPA upstream of the American Falls) required to stabilize the aquifer water balance. Horizontal lines represent the target $\left(0.26 \mathrm{~km}^{3} \mathrm{yr}^{-1}\right)$ and feasible $\left(0.75 \mathrm{~km}^{3} \mathrm{yr}^{-1}\right)$ bounds on existing managed aquifer recharge practice and infrastructure (IWRB, 2016). (d) Discharge and exported incidental returns at the watershed outlet at King Hill, Idaho. The horizontal line indicates the average discharge at the baseline.

creased, incidental recharge to the aquifer decreased, declining to $0.18 \mathrm{~km}^{3} \mathrm{yr}^{-1}$; incidental recharge flux did not depend on whether EAR was simulated or not. Groundwater abstractions also declined with increasing efficiency; however, for the most efficient parameterizations, abstractions exceeded incidental recharge, and the net recharge from irrigated crops $\left(I_{\text {rch }}\right)$ became negative, declining to $-0.8 \mathrm{~km}^{3} \mathrm{yr}^{-1}$ (Table 2). 
(a)

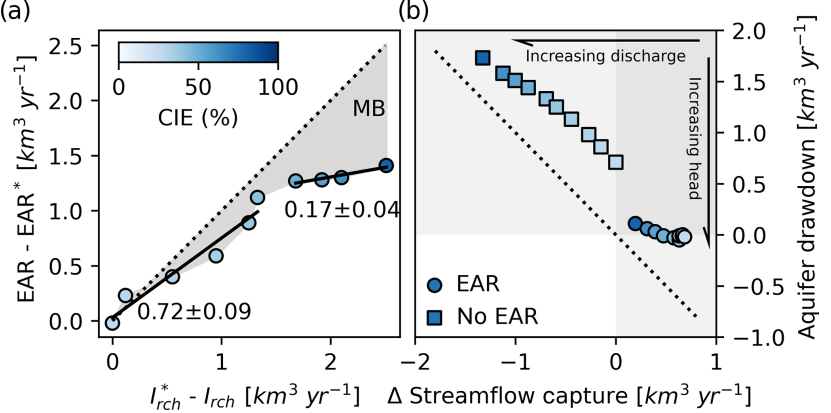

Figure 4. (a) Enhanced aquifer recharge (EAR) above the EAR required at the baseline $\left(\mathrm{EAR}^{*}\right)$ to ensure aquifer stabilization plotted against the reduction in net recharge from irrigation $\left(I_{\text {rch }}\right)$ from the baseline $\left(I_{\text {rch }}^{*}\right)$ as classical irrigation efficiency (CIE) increases. The dotted line represents equal increases in EAR and reductions in net recharge. All scenarios show that less additional EAR is required than is lost from net recharge as CIE increases; the magnitude is referred to as the management benefit (MB). Slopes of piecewise linear regressions (black lines) between two variables are shown with the standard error of the estimate. (b) Aquifer drawdown plotted against the change in basin streamflow capture $\left(Q^{*}-Q\right)$ with the dotted line representing equal changes to discharge from baseline and drawdown.

We hypothesized that the relative increase in EAR needed to stabilize the aquifer would be less than the loss of net irrigated recharge $\left(I_{\text {rch }}\right)$ resulting from increasing irrigation efficiency. The simulated water balance supported the hypothesis (Fig. 4a). For parameterizations more efficient than the baseline, the increase in EAR for each parameterization was less than the loss of the net irrigated recharge from the baseline, and the relationship between the two metrics appeared to be nonlinear (Fig. 4a). Approximately $72 \%$ of the lost net irrigated recharge was required as EAR to stabilize the aquifer for parameterizations Eff.A through Eff.E, and then only approximately $17 \%$ of the lost net irrigated recharge was required as EAR for parameterizations Eff.F through Eff.I (Fig. 4a). The abrupt change in the effectiveness of EAR in stabilizing the aquifer corresponds with an increasing proportion of direct (drip) irrigation for Eff.F through Eff.I (Table 1), reflecting the relatively larger reduction in the distribution uniformity parameter between sprinkler $(0.55)$ and direct $(0.05)$ than from surface (1.15) to sprinkler $(0.55)$, causing a rapidly decreased nonbeneficial consumption. The magnitude by which the increase in required EAR is less than the relative loss in the net irrigated recharge reflects the management benefit (MB; Eq. 2) that the enhanced aquifer recharge, combined with efficiency, has on aquifer balance (Fig. 4a). MB increased to a maximum of $1.3 \mathrm{~km}^{3} \mathrm{yr}^{-1}$ for Eff.I, which was the only parameterization that exceeded the $1.06 \mathrm{~km}^{3} \mathrm{yr}^{-1}$ EAR needed at the baseline to stabilize the aquifer.

For all simulations conducted, the rate of aquifer drawdown (negative $\frac{d V_{\text {ESPA }}}{\mathrm{d} t}$ ) was greater than the relative change in the flow out of the basin from the baseline (Fig. 4b). Changing flow out of the basin represents a change in streamflow capture, or how the use of water in the basin affects the flux leaving through the river. Simulations with EAR exhibited lower outlet discharge compared to the baseline (greater streamflow capture or negative $Q^{*}-Q-$ Fig. 4b), as a fraction of Snake River flow was diverted to aquifer replenishment. The rate of EAR controlled the rate of streamflow capture by explicitly adding water to the aquifer, and not through altering the head-dependent baseflow flux back to the river, since increasing EAR also increased baseflow. Note that we focus on changes in streamflow capture relative to baseline and do not make inferences about the absolute fluxes of streamflow capture associated with use of the ESPA. As classical irrigation efficiency increased both with and without EAR, the change in streamflow capture came closer to the rate of aquifer drawdown.

\section{Discussion}

\subsection{Aquifer reliance on incidental irrigation for recharge}

We found a nonlinearity in the volumes of enhanced aquifer recharge (EAR) required to stabilize the aquifer as more efficient irrigation technologies were employed. That is, incrementally smaller volumes of enhanced aquifer recharge (EAR) were needed compared to the net irrigated recharge lost due to using more efficient technologies (Fig. 4a). This applied only for incremental increases in EAR volumes above the requirements for aquifer stability at the baseline parameterization. The volume represented by the efficiency of the combined system from pairing increasing CIE with EAR, the management benefit (MB; Fig. 4a), demonstrates that the rate of increasing EAR is less than the rate that net recharge declines. However, the volumetric benefit only exceeded the baseline requirement of EAR for the most efficient (Eff.I) case, and the benefit was not evident for parameterization Eff.A. The management benefit is predominately attributed to the additional capture of Snake River discharge (Figs. 3 and 4) and by way of increasing irrigation water reuse (Table 2) and decreasing incidental returns (Fig. 3). This illustrates that in regions with conjunctively managed surface and groundwater sources like the USRB, increasing basinwide water resource availability via the combined implementation of managed aquifer recharge and changing irrigation efficiency can only be expected to capture more streamflow by transferring water to longer residence time compartments during seasons when water is more available.

Our simulations suggest several important implications of a conjunctive management strategy promoting aquifer recharge while increasing the efficiency of irrigation technology. The amount of EAR needed for a given technology parameterization always exceeded the corresponding rate of 
drawdown without EAR by $36 \%$ to $66 \%$. The excess EAR was needed because the aquifer drainage continues between peak EAR, which follows peak river flow from March to May, and peak irrigation demand (July) and because diverting water away from supply reservoirs shifts reliance to groundwater, which, in turn, required additional EAR for stabilization. The shift to more groundwater utilization is the primary reason for greater irrigation water reuse for simulations with EAR compared to simulations without (Table 2). Furthermore, the rate of the aquifer drawdown (up to $1.7 \mathrm{~km}^{3} \mathrm{yr}^{-1}$ without EAR; approximately $0 \mathrm{~km}^{3} \mathrm{yr}^{-1}$ with EAR) more closely approximated changing streamflow capture as CIE increased, meaning that the system converted a greater proportion of the captured streamflow to aquifer storage, bringing the change in fluxes into greater parity. Despite the increasing parity between the rate of drawdown and capture with increasing CIE, drawdown always exceeded the magnitude of the change in streamflow capture (Fig. 4b). This is an expected result because surface water is the dominant source for irrigation, and the aquifer is naturally located upgradient of the basin's outlet; interventions that add water to the aquifer (decrease drawdown), will eventually lead to increased downstream discharge (decreased streamflow capture), but the converse is not generally true. Therefore, increasing CIE without EAR will act to deplete the resource relied on by groundwater irrigators more than the impact that EAR would have on downstream users, at least in terms of volumetric shortfalls.

The rate of change in aquifer storage $\left(\frac{\mathrm{d} V_{\mathrm{ESPA}}}{\mathrm{d} t}\right)$ factors significantly in the preceding analysis, and an overestimation of the present-day rate of aquifer drawdown may shift values but is unlikely to change the general conclusions. At the baseline, we estimated $\frac{\mathrm{d} V_{\text {ESPA }}}{\mathrm{d} t}$ to be $-0.71 \mathrm{~km}^{3} \mathrm{yr}^{-1}$, which is a greater rate of drawdown than the $-0.34 \mathrm{~km}^{3} \mathrm{yr}^{-1}$ estimated by the ESPAM2.1 (IDWR, 2013), with the latter likely being more accurate given our underestimates of percolation losses described above. The rates of EAR we identified to stabilize the lumped representation of the ESPA exceeded both targets and feasible limits of managed aquifer recharge (IWRB, 2016, Fig. 4c). This potential limitation should be explored in future research focusing on evaluating specific management objectives.

Our simulations assumed a constant beneficial consumption, though the use and efficiency are often positively correlated due to the economic incentives to use more water when it is made available locally through efficiency measures (Contor and Taylor,2013; Grafton et al., 2018; Pfeiffer and Lin, 2014; Tran et al., 2019), and because prior appropriation doctrine requires that water rights holders use their full water right beneficially, essentially encouraging constant levels of water withdrawal regardless of CIE. In the USRB, it is reasonable to assume negligible slippage and rebound effects. Frequent droughts, the collective action of irrigation districts, and legal agreements between water user organizations out- side of the prior appropriation system, all work to incentivize reduced water withdrawals when possible (Gilmore, 2019). Moreover, a settlement between surface and groundwater irrigators (IDWR, 2015) details specific requirements to ensure stable aquifer head for both irrigation and downgradient outflow from springs. To the extent that beneficial use could increase with higher CIE, greater EAR would be required to meet the mandate of aquifer stabilization, or aquifer drawdown would increase without EAR for any given CIE relative to that simulated here.

The generalizable findings from these simulations have implications for similar semiarid basins relying on a combination of groundwater and seasonably available surface water. Achieving aquifer stabilization and increasing downstream discharge from combining increased CIE with EAR, as simulated here, would require significant investment in the hydro-infrastructure of the basin. In some systems, these investments may be a prerequisite for groundwater sufficiency (Scanlon et al., 2016). In these simulations, EAR was a prerequisite for aquifer stabilization because no tested CIE was able to create a stable aquifer with the existing agricultural production and natural recharge alone. In the USRB, the current head level targeted for stabilization is greater than the head existing in the basin prior to irrigation (Kjelstrom, 1995), and it generates increased rates of baseflow from springs. This issue is unique when considering many other semiarid basins relying on groundwater for irrigation that are managed against aquifer depletion below preirrigation heads (Bierkens and Wada, 2019). The primary adverse externality of EAR, aside from the technical considerations of feasibility, is decreasing watershed discharge on an annual basis, which would be undesirable for downstream users; however, increasing flow during the irrigation season can be expected (Van Kirk et al., 2020). We found that decreased downstream flow simulated here with EAR, which at 10.2 to $10.6 \mathrm{~km}^{3} \mathrm{yr}^{-1}$ still exceeds the observed record during the same period $\left(7.35 \mathrm{~km}^{3} \mathrm{yr}^{-1}\right)$, and existing requirements for instream flow (e.g., $4.1 \mathrm{~km}^{3} \mathrm{yr}^{-1}$; IWRB, 1985) to be greater than the existing model bias in outlet discharge.

\subsection{Irrigation reuse in the upper Snake River basin}

Incidental returns from irrigation were a major component of the basin's water balance and are therefore key for understanding basin-scale interpretations of system efficiency. Within the USRB, reuse of incidental returns generated during the model epoch currently makes up at least $9.9 \%$ of the gross irrigation and would increase to $14.6 \%$ if EAR was used to stabilize the aquifer (Table 2, Fig. 2). The baseline value of the irrigation water reuse is likely underestimated due to the low bias in gross irrigation, lower rate of net agricultural recharge relative to ESPAM2.1, and a high fraction of relict water composing the ESPA water volume in our simulations. As irrigation efficiency increased and incidental returns decreased both with and without EAR, the total reuse of 


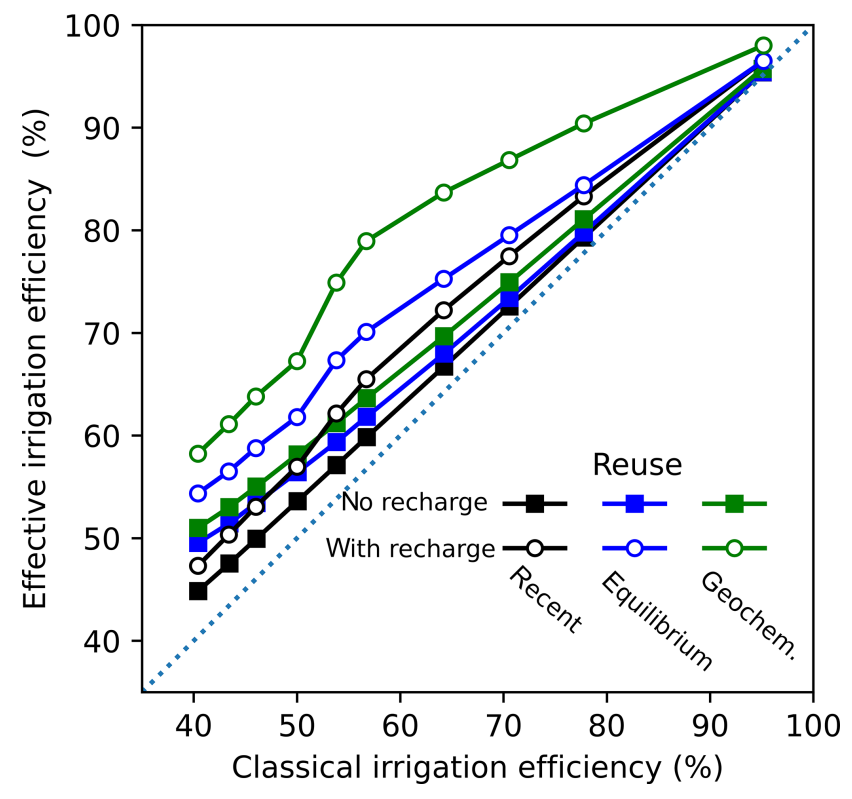

Figure 5. Effective irrigation efficiency plotted against the classical irrigation efficiency of each parameterization. Effective irrigation efficiency is calculated three ways based on the estimates of irrigation reuse as follows: near-term - simulated reuse, where incidental returns in aquifer abstractions are represented explicitly during the model epoch (3\%); equilibrium - incidental returns in the aquifer abstractions are assumed to be at equilibrium in the aquifer at ratio of incidental recharge to total recharge (Table 2); and geochemical - incidental returns in aquifer abstractions are assumed to be represented by an average estimated geochemically (Plummer et al., 2000; $75 \%$ ).

irrigation water declined (Table 2). However, the fraction of incidental returns that was ultimately used beneficially (beneficial reuse) exhibited very different behavior if EAR was simulated. With no EAR, beneficial reuse remained between $7 \%$ and $8 \%$ of the total incidental returns for all efficiency parameterizations. With EAR, the beneficial reuse increased steadily with CIE to $30 \%$ of the total incidental returns for parameterization Eff.I. As a result of the increasing beneficial reuse, basin-scale effective irrigation efficiency either increases faster (with EAR) or slower (without EAR) than the classical irrigation efficiency (Fig. 5).

Metrics such as the effective irrigation efficiency (EIE) provide a unified metric of efficiency that captures the reusability of incidental returns at the watershed scale (Haie and Keller, 2008). Generally, EIE is calculated using assumptions of the recoverability of irrigation returns; however, we calculate basinwide EIE using simulated recovered volumes and, thereby, incorporate explicit estimates of recovered returns. Water within the ESPA was primarily simulated as relict water; therefore, the simulations neglect a significant volume of irrigation returns stored within the aquifer from incidental recharge predating the model epoch. Our estimates of irrigation reuse are therefore low and reflect only the reuse of incidental return and subsequent abstractions from the aquifer during the model epoch. We calculate three estimates of EIE as follows: (1) near-term EIE - using the explicitly tracked incidental returns during the model epoch; (2) equilibrium EIE - assuming the equilibrium fraction of incidental returns in abstracted groundwater equals the ratio of incidental to natural recharge (Table 2); and (3) geochemical EIE - assuming that aquifer abstractions consist of a constant fraction of $75 \%$ incidental returns estimated geochemically by Plummer et al. (2000). Without enhanced recharge, the actual rate of recovery of incidental returns via irrigation was low, so effective irrigation efficiency is only slightly greater than classical irrigation efficiency at any parameterization (Fig. 5), and this reflects the large proportion of fresh snowmelt used to supply irrigation in most years (Fig. 2). With the enhanced recharge, the added reuse increases EIE faster than CIE for parameterizations Eff.A through Eff.G. Assuming equilibrium or geochemical estimates of returns in aquifer water increases the estimated EIE by $7 \%$ and $11 \%$ at the baseline, respectively. Moreover, improving irrigation efficiency from the baseline through parameterization Eff.E increases the rate at which EIE improves. The parameterizations that correspond with an increasing rate of EIE improvements are the same parameterizations that show a smaller increase in the management benefit, e.g., a smaller amount of additional EAR compensating for the loss of net agricultural recharge (Fig. 4a). Though the EIE captures a more complete picture of the effect of changing irrigation technology over the complete system, the high rate of increase in EIE for small changes in irrigation technology may overstate the benefits of intervention on the water balance of the entire basin as captured by the calculation of management benefit.

Incidental returns as a component of discharge at the basin outlet at King Hill, ID, was $0.84 \mathrm{~km}^{3} \mathrm{yr}^{-1}$ (approximately $8 \%$ of streamflow) at the baseline and declined as CIE increased (Table 2). Therefore, the recoverable incidental returns can be used beyond the USRB. With EAR, incidental returns in discharge were slightly higher than those without for each technology parameterization and declined to $0.04 \mathrm{~km}^{3} \mathrm{yr}^{-1}$ at Eff.I, thereby decreasing incidental returns as a fraction of flow to $0.3 \%$. Modernization acted to increase the unabstracted fraction of discharge leaving the basin, therefore benefitting downstream users while increasing aquifer drawdown. The addition of EAR captured more unabstracted streamflow in the basin, while maintaining a similar flux of exported incidental returns.

Decreasing the fraction of incidental returns in river flow would be expected to improve water quality in the river. However, increasing irrigation reuse implies further recycling of agricultural runoff, which tends toward greater acute water quality threats, such as salinization (Ghassemi et al., 1995; Qadir, 2016) and increasing nitrate concentration (Frans et al., 2012). Presently, neither soil salinization nor waterlogging are widespread in the USRB owing to existing conjunctive water abstractions and good drainage, 
but as irrigation technology modernizes in the USRB and excess irrigation water for flushing is reduced, isolated instances of salinization are becoming increasingly common (Ellsworth, 2004; Moore et al., 2011). While decreasing incidental recharge could exacerbate soil salinization if left unmanaged, both irrigation reuse and incidental returns in USRB export declined (Fig. 4; Table 2), which could potentially improve water quality to the ESPA and downstream users. Our definition of incidental returns included canal seepage, a major source of recharge to the ESPA. Canal seepage only represents a source of contaminates if they receive poorly managed runoff, which is not evaluated here. Therefore, in the USRB, incidental returns and reuse can only be loosely interpreted as an indicator of water quality, and fate and transport processes would be needed to assess the explicit fate of any agricultural contaminants. Considering the growing concerns of salinization associated with irrigated agriculture (Cañedo-Argüelles et al., 2013; Ghassemi et al., 1995), especially in semiarid and arid regions with increasing technological efficiencies (Banin and Fish, 1995; Carr et al., 2010; Tal, 2016), additional attention is needed to evaluate the trade-offs of managing soil salinization and the efficiency of irrigation technology.

\section{Conclusions}

Our simulations of the USRB characterize the limitations of relying exclusively on technological adaptations to address water shortfalls in semiarid regions. Technological modernization does not promote aquifer stabilization by itself in some contexts. Modernization without managed aquifer recharge (MAR) resulted in a greater loss from aquifer storage and increased downstream flow, undermining the groundwater resources needed for agriculture resiliency in this semiarid basin. Furthermore, we found that, through combined application of MAR and increasingly efficient irrigation technology, the potential increase in downstream flow was always less than the increased drawdown in the aquifer, meaning that less streamflow capture than drawdown was needed for similar crop production in a conjunctively managed system. By increasing MAR to values likely difficult to achieve in practice (IWRB, 2016), the system utilizes only a portion of the net irrigated recharge lost by modernization to stabilize the aquifer. The simulations tested demonstrate the trade-offs inherent in reducing nonconsumptive losses through modernization that have been explored in other regions with high gross irrigation reuse (Simons et al., 2015) and illustrate how modernization exports benefits to downstream users. The absence of clear evidence for significantly improved water availability with modernization that is predicted for global scales (e.g., Jägermeyr et al., 2015, 2016; Sauer et al., 2010) is because exported benefits (net increase in water availability) are absorbed by downstream users when analyzed at that scale (Grogan et al., 2017). How- ever, in a single headwater semiarid basin, there is a fundamental lack of parity between local groundwater users and downstream users; any intervention that improves aquifer storage necessarily also benefits downstream users eventually, while the converse is not necessarily true. Also, potential policy and comprehensive water management initiatives which are likely to co-occur with modernization (Gleick et al., 2011) can provide additional benefits to basin water budgets not realized solely by modernizing irrigation technology (Jägermeyr et al., 2015). The ineffectiveness of technological modernization in stabilizing the aquifer by itself may reflect the specific setting of the USRB that naturally favors nonconsumptive loss to nonbeneficial use via high percolation rates coupled with a straightforward avenue for local reuse via a productive aquifer and springs. Irrigation reuse declines as classical irrigation efficiency increases, but using MAR increased the reuse of incidental returns. Though we expected MAR to reduce the reuse of incidental returns through the introduction of more pristine water to the aquifer, the larger effect of shifting irrigation reliance towards groundwater from surface water was observed, thereby increasing reuse at the basin scale. The added reuse from implementing MAR in our simulations leads to effective irrigation efficiency increasing faster than classical irrigation efficiency. We would expect the nature of gross irrigation reuse in the USRB to be neither an isolated instance nor a general exemplar of water allocation issues, but it does provide an example of the complexity and lack of generalizability of specific interventions needed to achieve agricultural sustainability.

Data availability. Complete model simulation results are available through the Northwest Knowledge Network (https://doi.org/10.7923/w6b7-bh63) (Zuidema, 2020).

Supplement. The supplement related to this article is available online at: https://doi.org/10.5194/hess-24-5231-2020-supplement.

Author contributions. SZ primarily developed the new model code and the input data, created and ran the simulation experiments, created all the figures, and drafted the paper. DG assisted in the development of new model code and input data and edited the paper. RL provided guidance on the main research direction, assisted in creation of the simulation experiments, and edited the paper. AP revised the new model code, assisted with the input data preparation, and edited the paper. SG assisted in developing the input data and provided the introduction and background. PW also contributed to the introduction and background and edited the complete draft of the paper.

Competing interests. The authors declare that they have no conflict of interest. 
Acknowledgements. The authors acknowledge the technical support of Stanley Glidden and the constructive feedback provided by J. Matthew Davis on early drafts of the paper.

Financial support. This research has been supported by the National Science Foundation, Division of Social and Economic Sciences (grant no. 1639524), and the U.S. Department of Energy, Office of Science (grant no. DE-SC0016162).

Review statement. This paper was edited by Nunzio Romano and reviewed by Gijs Simons and two anonymous referees.

\section{References}

Abatzoglou, J. T.: Development of gridded surface meteorological data for ecological applications and modelling, Int. J. Climatol., 33, 121-131, https://doi.org/10.1002/joc.3413, 2013.

Adam, J. C., Haddeland, I., Su, F., and Lettenmaier, D. P.: Simulation of reservoir influences on annual and seasonal streamflow changes for the Lena, Yenisei, and Ob' rivers, J. Geophys. Res.Atmos., 112, D24114, https://doi.org/10.1029/2007JD008525, 2007.

Allen, R. G., Pereira, L. S., Raes, D., and Smith, M.: Crop evapotranspiration - Guidelines for computing crop water requirements, FAO Irrigation and drainage paper 56, FAO, Rome, 300, 1998.

Arshad, M., Guillaume, J. H. A., and Ross, A.: Assessing the Feasibility of Managed Aquifer Recharge for Irrigation under Uncertainty, Water, 6, 2748-2769, https://doi.org/10.3390/w6092748, 2014.

Banin, A. and Fish, A.: Secondary desertification due to salinization of intensively irrigated lands: The Israeli experience, Environ. Monit. Assess., 37, 17-37, https://doi.org/10.1007/BF00546878, 1995.

Bavi, A., Kashuli, H. A., Boroomand, S., Naseri, A., and Albaji, M.: Evaporation Losses from Sprinkler Irrigation Systems under Various Operating Conditions, J. Appl. Sci., 9, 597-600, https://doi.org/10.3923/jas.2009.597.600, 2009.

Bierkens, M. F. P. and Wada, Y.: Non-renewable groundwater use and groundwater depletion: a review, Environ. Res. Lett., 14, 063002, https://doi.org/10.1088/1748-9326/ab1a5f, 2019.

Bogacki, P. and Shampine, L. F.: A 3(2) pair of Runge - Kutta formulas, Appl. Math. Lett., 2, 321-325, https://doi.org/10.1016/0893-9659(89)90079-7, 1989.

Boggs, K. G., Kirk, R. W. V., Johnson, G. S., Fairley, J. P., and Porter, P. S.: Analytical Solutions to the Linearized Boussinesq Equation for Assessing the Effects of Recharge on Aquifer Discharge1, JAWRA J. Am. Water Resour. Assoc., 46, 1116-1132, https://doi.org/10.1111/j.1752-1688.2010.00479.x, 2010.

Burt, C. M., Clemmens, A. J., Strelkoff, T. S., Solomon, K. H., Bliesner, R. D., Hardy, L. A., Howell, T. A., and Eisenhauer, D. E.: Irrigation Performance Measures: Efficiency and Uniformity, J. Irrig. Drain. E., 123, 423-442, https://doi.org/10.1061/(ASCE)0733-9437(1997)123:6(423), 1997.
Cañedo-Argüelles, M., Kefford, B. J., Piscart, C., Prat, N., Schäfer, R. B., and Schulz, C.-J.: Salinisation of rivers: An urgent ecological issue, Environ. Pollut., 173, 157-167, https://doi.org/10.1016/j.envpol.2012.10.011, 2013.

Carr, G., Nortcliff, S., and Potter, R. B.: Water reuse for irrigated agriculture in Jordan: challenges of soil sustainability and the role of management strategies, Philos. T. R. Soc. A, 368, 53155321, https://doi.org/10.1098/rsta.2010.0181, 2010.

Center For International Earth Science Information Network and Socioeconomic Data and Applications Center, Columbia University: Gridded Population of the World, Version 4 (GPWv4): Population Density, 2016.

Contor, B. A. and Taylor, R. G.: Why improving irrigation efficiency increases total volume of consumptive use: irrigation efficiency increases consumptive use, Irrig. Drain., 62, 273-280, https://doi.org/10.1002/ird.1717, 2013.

Covington, H. R. and Weaver, J. N.: Geologic map and profiles of the north wall of the Snake River Canyon, Thousand Springs and Niagara quadrangles, Idaho, USGS Numbered Series, U.S. Geological Survey, Reston, VA, available at: http://pubs.er.usgs.gov/ publication/i1947C (last access: 1 January 2018), 1991.

Dewandel, B., Gandolfi, J.-M., de Condappa, D., and Ahmed, S.: An efficient methodology for estimating irrigation return flow coefficients of irrigated crops at watershed and seasonal scale, Hydrol. Process., 22, 1700-1712, https://doi.org/10.1002/hyp.6738, 2008.

Dieter, C. A., Maupin, M. A., Caldwell, R. R., Harris, M. A., Ivahnenko, T. I., Lovelace, J. K., Barber, N. L., and Linsey, K. S.: Estimated use of water in the United States in 2015, USGS Numbered Series, U.S. Geological Survey, Reston, VA, available at: http://pubs.er.usgs.gov/publication/cir1441, last access: 13 November 2018.

Dillon, P.: Future management of aquifer recharge, Hydrogeol. J., 13, 313-316, https://doi.org/10.1007/s10040-004-0413-6, 2005.

Dillon, P., Stuyfzand, P., Grischek, T., Lluria, M., Pyne, R. D. G., Jain, R. C., Bear, J., Schwarz, J., Wang, W., Fernandez, E., Stefan, C., Pettenati, M., van der Gun, J., Sprenger, C., Massmann, G., Scanlon, B. R., Xanke, J., Jokela, P., Zheng, Y., Rossetto, R., Shamrukh, M., Pavelic, P., Murray, E., Ross, A., Bonilla Valverde, J. P., Palma Nava, A., Ansems, N., Posavec, K., Ha, K., Martin, R., and Sapiano, M.: Sixty years of global progress in managed aquifer recharge, Hydrogeol. J., 27, 1-30, https://doi.org/10.1007/s10040-018-1841-z, 2019.

Dillon, P., Fernández Escalante, E., Megdal, S. B., and Massmann, G.: Managed Aquifer Recharge for Water Resilience, Water, 12, 1846, https://doi.org/10.3390/w12071846, 2020.

Ellsworth, J.: Saline and Sodic Soils in Idaho, in: Proceedings of the Idaho Nutrient Management Conference, Twin Falls, ID, 2004.

Fereday, J. C., Meyer, C. H., and Creamer, M. C.: The Acquisition, Use, Transfer, Administration, and Management Of Water Rights in Idaho, LLP, Givens Pursley, 499 pp., 2018.

Ferraro, P. J., Sanchirico, J. N., and Smith, M. D.: Causal inference in coupled human and natural systems, P. Natl. Acad. Sci. USA, 116, 5311-5318, https://doi.org/10.1073/pnas.1805563115, 2019.

Foley, J. A., Ramankutty, N., Brauman, K. A., Cassidy, E. S., Gerber, J. S., Johnston, M., Mueller, N. D., O'Connell, C., Ray, D. K., West, P. C., Balzer, C., Bennett, E. M., Carpenter, S. R., Hill, J., Monfreda, C., Polasky, S., Rockström, 
J., Sheehan, J., Siebert, S., Tilman, D., and Zaks, D. P. M.: Solutions for a cultivated planet, Nature, 478, 337-342, https://doi.org/10.1038/nature10452, 2011.

Foster, S. and van Steenbergen, F.: Conjunctive groundwater use: a "lost opportunity" for water management in the developing world?, Hydrogeol. J., 19, 959-962, https://doi.org/10.1007/s10040-011-0734-1, 2011.

Frans, L., Rupert, M., Hunt Jr., C., and Skinner, K.: Groundwater quality in the Columbia Plateau, Snake River Plain, and Oahu basaltic-rock and basin-fill aquifers in the Northwestern United States and Hawaii, 1992-2010, Scientific Investigations Report, U.S. Geological Survey, Reston, VA, 2012.

Frederiksen, H. D. and Allen, R. G.: A common basis for analysis, evaluation and comparison of offstream water uses, Water Int., 36, 266-282, https://doi.org/10.1080/02508060.2011.580449, 2011.

Garabedian, S. P.: Hydrology and digital simulation of the regional aquifer system, eastern Snake River Plain, Idaho, USGS Numbered Series, U.S. Government Printing Office, available at: http://pubs.er.usgs.gov/publication/pp1408F (last access: 18 January 2018), 1992.

Gelaro, R., McCarty, W., Suárez, M. J., Todling, R., Molod, A., Takacs, L., Randles, C. A., Darmenov, A., Bosilovich, M. G., Reichle, R., Wargan, K., Coy, L., Cullather, R., Draper, C., Akella, S., Buchard, V., Conaty, A., da Silva, A. M., Gu, W., Kim, G.K., Koster, R., Lucchesi, R., Merkova, D., Nielsen, J. E., Partyka, G., Pawson, S., Putman, W., Rienecker, M., Schubert, S. D., Sienkiewicz, M., and Zhao, B.: The Modern-Era Retrospective Analysis for Research and Applications, Version 2 (MERRA-2), J. Climate, 30, 5419-5454, https://doi.org/10.1175/JCLI-D-160758.1, 2017.

Ghassemi, F., Jakeman, A. J., Nix, H. A., Australian National University, and Centre for Resource and Environmental Studies: Salinisation of land and water resources: human causes, extent, management, and case studies, NSW University Press, Sydney, N.S.W., Australia, 1995.

Gilmore, S.: Assessing the Adaptive Capacity of Idaho's Magic Valley As a Complex Social-Ecological System, MS, University of Idaho, Moscow, ID, USA, 2019.

Gleick, P. H., Christian-Smith, J., and Cooley, H.: Water-use efficiency and productivity: rethinking the basin approach, Water Int., 36, 784-798, https://doi.org/10.1080/02508060.2011.631873, 2011.

Grafton, R. Q., Williams, J., Molle, F., Ringler, C., Steduto, P., Udall, B., Wheeler, S. A., Wang, Y., Garrick, D., and Allen, R. G.: The paradox of irrigation efficiency, Science, 361, 748-750, 2018.

Grogan, D. S.: Global and regional assessments of unsustainable groundwater use in irrigated agriculture, $\mathrm{PhD}$, University of New Hampshire, Durham, NH, May, available at: https://scholars.unh. edu/dissertation/2260/ (last access: 20 June 2018), 2016.

Grogan, D. S., Wisser, D., Prusevich, A., Lammers, R. B., and Frolking, S.: The use and re-use of unsustainable groundwater for irrigation: a global budget, Environ. Res. Lett., 12, 034017, https://doi.org/10.1088/1748-9326/aa5fb2, 2017.

Guyennon, N., Salerno, F., Portoghese, I., and Romano, E.: Climate Change Adaptation in a Mediterranean Semi-Arid Catchment: Testing Managed Aquifer Recharge and Increased Surface Reser- voir Capacity, Water, 9, 689, https://doi.org/10.3390/w9090689, 2017.

Haie, N. and Keller, A. A.: Effective Efficiency as a Tool for Sustainable Water Resources Management, JAWRA J. Am. Water Resour. Assoc., 44, 961-968, https://doi.org/10.1111/j.17521688.2008.00194.x, 2008.

Hamon, W. R.: Computation of direct runoff amounts from storm rainfall, in: International Association of Hydrological Sciences Publications, 63, 52-62, International Association of Hydrological Sciences, Oxford, MS, 1963.

Han, W., Yang, Z., Di, L., and Mueller, R.: CropScape: A Web service based application for exploring and disseminating US conterminous geospatial cropland data products for decision support, Comput. Electron. Agr., 84, 111-123, https://doi.org/10.1016/j.compag.2012.03.005, 2012.

IDWR: Enhanced Snake Plain Aquifer Model Version 2.1: Final Report, Idaho Department of Water Resources, Boise ID, 2013.

IDWR: Administrative Basins, available at: https://data-idwr.opendata.arcgis.com/datasets/

fb0df7d688a04074bad92ca8ef74cc26_4 (last access: 1 June 2018), 2015.

IWRB: Resolution Adopting Swan Falls Amendments to Policy 32 of State Water Plan, Idaho Department of Water Resources, Boise, ID, 1985.

IWRB: Eastern Snake Plain Aquifer (ESPA) Comprehensive Aquifer Management Plan, Idaho Water Resources Board, Boise, ID, available at: https://www.idwr.idaho.gov/waterboard/ WaterPlanning/CAMP/ESPA/PDFs/ESPA_CAMP_lowres.pdf (last access: 12 November 2018), 2009.

IWRB: Final Report: Eastern Snake Plain Aquifer (ESPA) Review of Comprehensive Managed Aquifer Recharge Program, Idaho Water Resources Board, Boise, ID, available at: https://idwr. idaho.gov/files/iwrb/2016/201603-CH2M-Recharge-Report.pdf (last access: 12 November 2018), 2016.

Jägermeyr, J., Gerten, D., Heinke, J., Schaphoff, S., Kummu, M., and Lucht, W.: Water savings potentials of irrigation systems: global simulation of processes and linkages, Hydrol. Earth Syst. Sci., 19, 3073-3091, https://doi.org/10.5194/hess-19-3073-2015, 2015.

Jägermeyr, J., Gerten, D., Schaphoff, S., Heinke, J., Lucht, W., and Rockström, J.: Integrated crop water management might sustainably halve the global food gap, Environ. Res. Lett., 11, 025002, https://doi.org/10.1088/1748-9326/11/2/025002, 2016.

Keller, A. and Keller, J.: Effective Efficiency: A Water Use Efficiency Concept for Allocating Freshwater Resources, in Discussion Paper 22, p. 20, Center for Economic Policy Studies, Winrock International, Arlington, VA, 1995.

Keller, A. A., Keller, J., Seckler, D. W., Garces-Restrepo, C., and International Water Management Institute: Integrated water resource systems: theory and policy implications, International Water Management Institute, Colombo, Sri Lanka, 1996.

Kjelstrom, L. C.: Streamflow gains and losses in the Snake River and ground-water budgets for the Snake River plain, Idaho and eastern Oregon, USGS Numbered Series, available at: http://pubs.er.usgs.gov/publication/pp1408C (last access: 8 January 2018), 1995.

Konikow, L. F. and Leake, S. A.: Depletion and Capture: Revisiting "The Source of Water Derived from Wells," Groundwater, 52, 100-111, https://doi.org/10.1111/gwat.12204, 2014. 
Lankford, B.: Fictions, fractions, factorials and fractures; on the framing of irrigation efficiency, Agric. Water Manag., 108, 2738, https://doi.org/10.1016/j.agwat.2011.08.010, 2012.

Lehner, B., Verdin, K., and Jarvis, A.: New Global Hydrography Derived From Spaceborne Elevation Data, Eos Trans. AGU, 89, 93-94, https://doi.org/10.1029/2008EO100001, 2008.

Lin, Y. and Garcia, L. A.: Assessing the Impact of Irrigation Return Flow on River Salinity for Colorado's Arkansas River Valley, J. Irrig. Drain. E., 138, 406-415, https://doi.org/10.1061/(ASCE)IR.1943-4774.0000410, 2012.

Lindholm, G. F.: Summary of the Snake River plain Regional Aquifer-System Analysis in Idaho and eastern Oregon, USGS Numbered Series, U.S. Government Printing Office, available at: http://pubs.er.usgs.gov/publication/pp1408A (last access: 18 October 2018), 1996.

Lovin, H. T.: Dreamers, Schemers, and Doers of Idaho Irrigation, Agr. Hist., 76, 232-243, 2002.

Maliva, R. G.: Economics of Managed Aquifer Recharge, Water, 6, 1257-1279, https://doi.org/10.3390/w6051257, 2014.

Masaki, Y., Hanasaki, N., Biemans, H., Schmied, H. M., Tang, Q., Wada, Y., Gosling, S. N., Takahashi, K., and Hijioka, Y.: Intercomparison of global river discharge simulations focusing on dam operation - multiple models analysis in two casestudy river basins, Missouri-Mississippi and Green-Colorado, Environ. Res. Lett., 12, 055002, https://doi.org/10.1088/17489326/aa57a8, 2017.

Maupin, M. A., Kenny, J. F., Hutson, S. S., Lovelace, J. K., Barber, N. L., and Linsey, K. S.: Estimated use of water in the United States in 2010, U.S. Geological Survey, Reston, Virginia, 2014.

McLean, R. K., Ranjan, R. S., and Klassen, G.: Spray evaporation losses from sprinkler irrigation systems, Can. Agr. Eng., 42, 1-8, 2000.

McVay, M.: Incorporating Recharge Limitations into the Prioritization of Aquifer Recharge Sites Based on Hydrologic Benefits Using ESPAM2.1, Open File Report, IDWR, Boise, ID, 2015.

Monteith, J. L.: Evaporation and environment: the state and movement of water in living organisms, Symposium of the Society for Experimental Biology, 19, 205-224, 1965.

Moore, A., Zglobicki, S., and Olsen, N.: Manure Management in Potatoes: Salt Accumulations in Idaho Soils, in Proceedings of the Idaho Potato Conference, Wiley Online Library, Twin Falls, ID, 2011.

Moreland, J. A.: Digital-model analysis of the effects of wateruse alternatives on spring discharges Gooding and Jerome Counties, Idaho, Other Government Series, Idaho Department of Water Resources, Boise, ID, available at: http://pubs.er.usgs.gov/ publication/70042717 (last access: 3 January 2018), 1976.

Niswonger, R. G., Morway, E. D., Triana, E., and Huntington, J. L.: Managed aquifer recharge through off-season irrigation in agricultural regions, Water Resour. Res., 53, 6970-6992, https://doi.org/10.1002/2017WR020458, 2017.

Penny, G., Mondal, M. S., Biswas, S., Bolster, D., Tank, J. L., and Müller, M. F.: Using Natural Experiments and Counterfactuals for Causal Assessment: River Salinity and the Ganges Water Agreement, Water Resour. Res., 56, e2019WR026166, https://doi.org/10.1029/2019WR026166, 2020.

Perry, C.: Accounting for water use: Terminology and implications for saving water and increasing production, Agric. Water Manag., 98, 1840-1846, https://doi.org/10.1016/j.agwat.2010.10.002, 2011.

Pfeiffer, L. and Lin, C.-Y. C.: Does efficient irrigation technology lead to reduced groundwater extraction? Empirical evidence, J. Environ. Econom. Manag., 67, 189-208, https://doi.org/10.1016/j.jeem.2013.12.002, 2014.

Plummer, L. N., Rupert, M. G., Busenberg, E., and Schlosser, P.: Age of Irrigation Water in Ground Water from the Eastern Snake River Plain Aquifer, South-Central Idaho, Ground Water, 38, 264-283, https://doi.org/10.1111/j.17456584.2000.tb00338.x, 2000.

Qadir, M.: Policy Note: Reversing Salt-Induced Land Degradation Requires Integrated Measures, Water Economics and Policy, 02, 1671001, https://doi.org/10.1142/S2382624X16710016, 2016.

Rosa, W. (Ed.): Transforming Our World: The 2030 Agenda for Sustainable Development, in A New Era in Global Health, Springer Publishing Company, New York, NY, 2017.

Samal, N. R., Wollheim, W., Zuidema, S., Stewart, R., Zhou, Z., Mineau, M., Borsuk, M., Gardner, K., Glidden, S., Huang, T., Lutz, D., Mavrommati, G., Thorn, A., Wake, C., and Huber, M.: A coupled terrestrial and aquatic biogeophysical model of the Upper Merrimack River watershed, New Hampshire, to inform ecosystem services evaluation and management under climate and land-cover change, Ecol. Soc., 22, 18, https://doi.org/10.5751/ES-09662-220418, 2017.

Sauer, T., Havlík, P., Schneider, U. A., Schmid, E., Kindermann, G., and Obersteiner, M.: Agriculture and resource availability in a changing world: The role of irrigation, Water Resour. Res., 46, W06503, https://doi.org/10.1029/2009WR007729, 2010.

Scanlon, B. R., Reedy, R. C., Faunt, C. C., Pool, D., and Uhlman, K.: Enhancing drought resilience with conjunctive use and managed aquifer recharge in California and Arizona, Environ. Res. Lett., 11, 035013, https://doi.org/10.1088/17489326/11/3/035013, 2016.

Scherberg, J., Baker, T., Selker, J. S., and Henry, R.: Design of Managed Aquifer Recharge for Agricultural and Ecological Water Supply Assessed Through Numerical Modeling, Water Resour Manage, 28, 4971-4984, https://doi.org/10.1007/s11269014-0780-2, 2014.

Simons, G. W. H., Bastiaanssen, W. G. M., and Immerzeel, W. W.: Water reuse in river basins with multiple users: A literature review, J. Hydrol., 522, 558-571, https://doi.org/10.1016/j.jhydrol.2015.01.016, 2015.

Steinfeld, H., Gerber, P., Wassenaar, T., Castel, V., Rosales, M., and de Haan, C.: Livestock's long shadow, available at: http: //www.fao.org/docrep/010/a0701e/a0701e00.HTM (last access: 9 August 2018), 2006.

Stewart, R. J., Wollheim, W. M., Miara, A., Vörösmarty, C. J., Fekete, B., Lammers, R. B., and Rosenzweig, B.: Horizontal cooling towers: riverine ecosystem services and the fate of thermoelectric heat in the contemporary Northeast US, Environ. Res. Lett., 8, 025010, https://doi.org/10.1088/1748-9326/8/2/025010, 2013.

Tal, A.: Rethinking the sustainability of Israel's irrigation practices in the Drylands, Water Res., 90, 387-394, https://doi.org/10.1016/j.watres.2015.12.016, 2016.

Trabucco, A. and Zomer, R.: Global Aridity Index and Potential Evapotranspiration (ET0) Climate Database v2, Figshare, https://doi.org/10.6084/m9.figshare.7504448.v3, 2019. 
Tran, D., Kovacs, K., and Wallander, S.: Long run optimization of landscape level irrigation through managed aquifer recharge or expanded surface reservoirs, J. Hydrol., 579, 124220, https://doi.org/10.1016/j.jhydrol.2019.124220, 2019.

Tran, D. Q., Kovacs, K. F., and West, G. H.: Spatial economic predictions of managed aquifer recharge for an agricultural landscape, Agric. Water Manag., 241, 106337, https://doi.org/10.1016/j.agwat.2020.106337, 2020.

Uddin, J., Smith, R., Hancock, N., and Foley, J. P.: Droplet evaporation losses during sprinkler irrigation: an overview, in Australian Irrigation Conference and Exibition 2010: Proceedings, edited by K. Montagu, pp. 1-10, Irrigation Australia Ltd., Sydney, Australia, available at: https://eprints.usq.edu.au/9004/ 1/Uddin_Smith_Hancock_Foley_IAL2010_PV.pdf (last access: 2 April 2019), 2010.

USACE: National inventory of dams, available at: http://nid.usace. army.mil (last access: 17 January 2020), 2016.

USDA NASS: 2012 Census of Agriculture, Ag Census Web Maps, available at: http://www.nass.usda.gov/Publications/AgCensus/ 2012/Online_Resources/Ag_Census_Web_Maps/Overview (last access: 2 July 2019), 2014.

USGS: National Hydrography Dataset (NHD), available at: https://www.usgs.gov/core-science-systems/ngp/ national-hydrography, last access: 16 April 2019.

Vanham, D., Hoekstra, A. Y., Wada, Y., Bouraoui, F., de Roo, A., Mekonnen, M. M., van de Bund, W. J., Batelaan, O., Pavelic, P., Bastiaanssen, W. G. M., Kummu, M., Rockström, J., Liu, J., Bisselink, B., Ronco, P., Pistocchi, A., and Bidoglio, G.: Physical water scarcity metrics for monitoring progress towards SDG target 6.4: An evaluation of indicator 6.4.2 "Level of water stress", Sci. Total Environ., 613-614, 218-232, https://doi.org/10.1016/j.scitotenv.2017.09.056, 2018.

Van Kirk, R. W., Contor, B. A., Morrisett, C. N., Null, S. E., and Loibman, A. S.: Potential for Managed Aquifer Recharge to Enhance Fish Habitat in a Regulated River, Water, 12, 673, https://doi.org/10.3390/w12030673, 2020.

Vörösmarty, C. J., Moore, B., Grace, A. L., Gildea, M. P., Melillo, J. M., Peterson, B. J., Rastetter, E. B., and Steudler, P. A.: Continental scale models of water balance and fluvial transport: An application to South America, Global Biogeochem. Cycles, 3, 241-265, https://doi.org/10.1029/GB003i003p00241, 1989.
Whitehead, R. L.: Geohydrologic framework of the Snake River plain regional aquifer system, Idaho and eastern Oregon, USGS Numbered Series, U.S. Government Printing Office, available at: http://pubs.er.usgs.gov/publication/pp1408B (last access: 3 January 2018), 1992.

Willmott, C. J., Rowe, C. M., and Mintz, Y.: Climatology of the terrestrial seasonal water cycle, J. Climatol., 5, 589-606, https://doi.org/10.1002/joc.3370050602, 1985.

Wisser, D., Frolking, S., Douglas, E. M., Fekete, B. M., Vörösmarty, C. J., and Schumann, A. H.: Global irrigation water demand: Variability and uncertainties arising from agricultural and climate data sets, Geophys. Res. Lett., 35, L24408, https://doi.org/10.1029/2008GL035296, 2008.

Wisser, D., Fekete, B. M., Vörösmarty, C. J., and Schumann, A. H.: Reconstructing 20th century global hydrography: a contribution to the Global Terrestrial Network- Hydrology (GTN-H), Hydrol. Earth Syst. Sci., 14, 1-24, https://doi.org/10.5194/hess14-1-2010, 2010.

Wulfhorst, J. D. and Glenn, E.: Irrigation, community, and historical development along the upper Snake River, Agr. Hist., 76, 434 447, 2002.

Yaraghi, N., Ronkanen, A., Darabi, H., Kløve, B., and Torabi Haghighi, A.: Impact of managed aquifer recharge structure on river flow regimes in arid and semi-arid climates, Sci. Total Environ., 675, 429-438, https://doi.org/10.1016/j.scitotenv.2019.04.253, 2019.

Zuidema, S.: ReFEWS - Interplay of changing irrigation technologies and water reuse - Modeling Results, https://doi.org/10.7923/w6b7-bh63, 2020.

Zuidema, S., Wollheim, W., Mineau, M. M., Green, M. B., and Stewart, R. J.: Controls of Chloride Loading and Impairment at the River Network Scale in New England, J. Environ. Qual., 47, 839-847, https://doi.org/10.2134/jeq2017.11.0418, 2018. 